\title{
Laccases-Versatile Enzymes Used to Reduce Environmental Pollution
}

\author{
Gigel Paraschiv ${ }^{1}$, Mariana Ferdes ${ }^{1, *}$, Mariana Ionescu ${ }^{1}$, Georgiana Moiceanu ${ }^{2} \mathbb{D}$, Bianca Stefania Zabava ${ }^{1}$ \\ and Mirela Nicoleta Dinca ${ }^{1}$
}

check for updates

Citation: Paraschiv, G.; Ferdes, M.; Ionescu, M.; Moiceanu, G.; Zabava, B.S.; Dinca, M.N. Laccases-Versatile Enzymes Used to Reduce Environmental Pollution. Energies 2022, 15, 1835. https://doi.org/ 10.3390/en15051835

Academic Editors: Talal Yusaf and Alok Kumar Patel

Received: 14 January 2022 Accepted: 28 February 2022 Published: 2 March 2022

Publisher's Note: MDPI stays neutral with regard to jurisdictional claims in published maps and institutional affiliations.

Copyright: (C) 2022 by the authors. Licensee MDPI, Basel, Switzerland. This article is an open access article distributed under the terms and conditions of the Creative Commons Attribution (CC BY) license (https:// creativecommons.org/licenses/by/ $4.0 /)$
1 Department of Biotechnical Systems, Politehnica University of Bucharest, 060042 Bucharest, Romania; gigel.paraschiv@upb.ro (G.P.); mariana.ionescu@upb.ro (M.I.); bianca.dragoiu@upb.ro (B.S.Z.); mirela.dinca@upb.ro (M.N.D.)

2 Department of Management and Entrepreneurship, Politehnica University of Bucharest, 060042 Bucharest, Romania; georgiana.moiceanu@upb.ro

* Correspondence: mferdes@upb.ro; Tel.: +40-729-821-256

\begin{abstract}
The accumulation of waste and toxic compounds has become increasingly harmful to the environment and human health. In this context, the use of laccases has become a focus of interest, due to the properties of these versatile enzymes: low substrate specificity, and water formation as a non-toxic end product. Thus, we begin our study with a general overview of the importance of laccase for the environment and industry, starting with the sources of laccases (plant, bacterial and fungal laccases), the structure and mechanism of laccases, microbial biosynthesis, and the immobilization of laccases. Then, we continue with an overview of agro-waste treatment by laccases wherein we observe the importance of laccases for the biodisponibilization of substrates and the biodegradation of agro-industrial byproducts; we then show some aspects regarding the degradation of xenobiotic compounds, dyes, and pharmaceutical products. The objective of this research is to emphasize and fully investigate the effects of laccase action on the decomposition of lignocellulosic materials and on the removal of harmful compounds from soil and water, in order to provide a sustainable solution to reducing environmental pollution.
\end{abstract}

Keywords: micro-organisms; biosynthesis; agro-waste; dyes; xenobiotics; pharmaceuticals; biodegradation

\section{Introduction}

The diversity of enzymes synthesized by micro-organisms during their metabolism contributes in profound ways to the degradation of organic or inorganic compounds in the environment, and plays a significant role in practical endeavors related to agriculture, industrial processes, and waste treatment. The soil and water form complex eco-systems that support a wide variety of micro-organisms that fulfill a dynamic role in biogeochemical cycles.

Laccases (EC 1.10.3.2, p-diphenol: dioxygen oxidoreductase) are enzymes that contain copper atoms in the active site, which catalyze the oxidation reaction of diverse substrates such as phenolic and aromatic molecules (ortho- and para-diphenols, amino phenols, methoxy-phenols, poly-phenols), aliphatic amines, and inorganic cations, resulting in water as a product of reduction in molecular oxygen [1]. Due to their properties, laccases are rightly considered as "green catalysts" [2].

\subsection{Importance of Laccases for Environment and Industry}

In recent times, laccases have been continuously used in many domains, such as the food industry (wine stabilization, fruit juice clarification, baking, and sugar beet pectin production); the textile industry (fiber biobleaching, denim washing); polymer synthesis and green nanoparticle synthesis; the paper and pulp industry (delignification of pulp, 
deinking of paper); biosensors; the decomposition of lignocellulosic material used as substrate in various processes; etc. [3].

Along with hydrolytic enzymes, laccases are of increasing interest; they can be used with remarkable results in the treatment of environmental pollutants, for the degradation of household waste, of and various compounds resulting from industry and agriculture.

As the accumulation of various substances with more-or-less dangerous potential in the environment has increased in recent times, the need for environmental restoration should capitalize on the biodegradative potential of laccases. These versatile enzymes have a low specificity and, therefore, catalyze the transformation of a large number of substrates and generate only water molecules as a by-product $[4,5]$. Consequently, the use of laccases is becoming more widespread in the treatment of waste from the agriculture and food industries; the degradation of pesticides; drug and cosmetic residues; the decolorization of dyes; the degradation of residues of the pulp and paper industry; etc. (Figure 1).

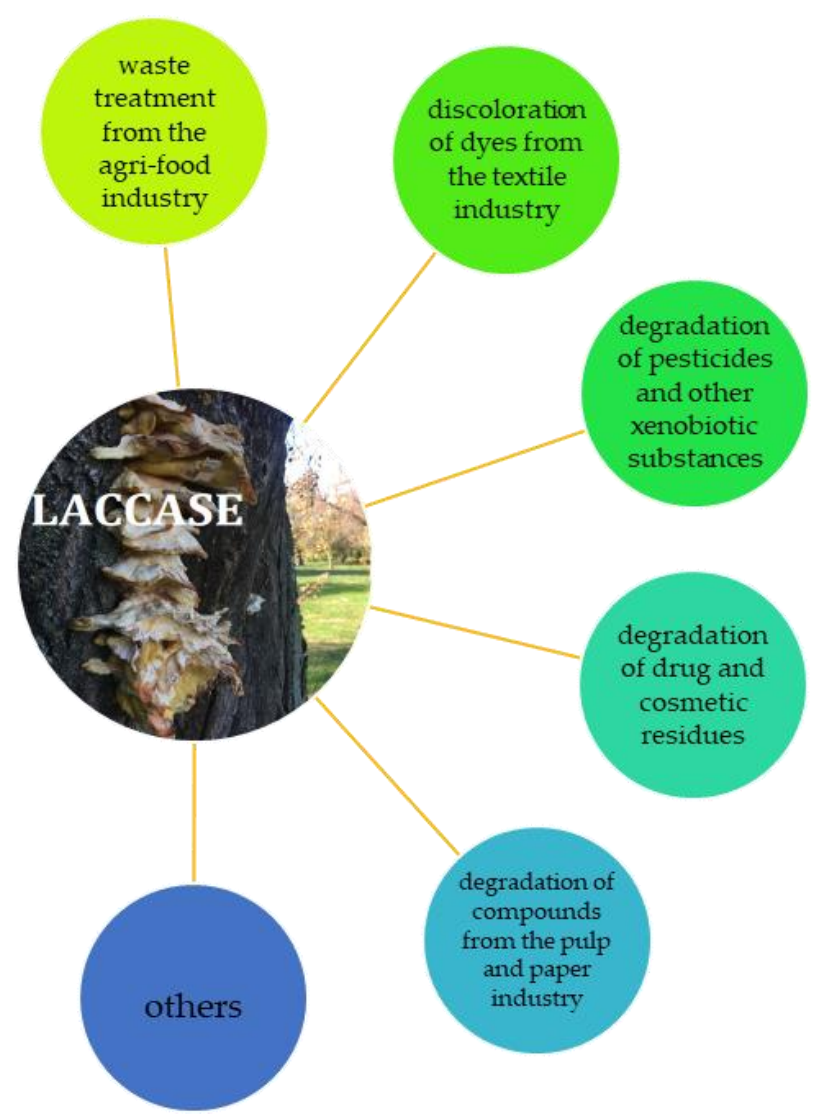

Figure 1. The use of laccases for the degradation of waste and hazardous compounds (authors creation).

\subsection{Sources of Laccases}

\subsubsection{Plant Laccases}

The first mention of laccases was made by Yoshida, who discovered their presence in the sumac, in 1883 [6]. Since then, it has been shown that these enzymes are produced by plants, insects, lichens, bacteria, and fungi. Among the plants that synthesize laccases are pears, turnips, cabbages, apples, potatoes, asparagus, and more [1]. There are several studies on laccases isolated from Pinus taeda, Acer pseudoplatanus, Nicotiana tabacum, P. trichocarpa, Liriodendron tulipifera, Lolium perenne, A. thaliana, Zea mays, Oryza sativa, Saccharum officinarum, Brassica napus, and Brachypodium distachyon. In plants, laccases are mainly involved in the processes of lignification, iron metabolism, defense and protection against environmental stresses, and the repair of damaged tissues [7]. 


\subsubsection{Bacterial Laccases}

In their natural habitat, micro-organisms (Figure 2) are able to produce laccases in the process of degradation of the substrate, as well as in the processes of protection, virulence and pathogenicity, sporulation, and pigment synthesis [8]. The best known bacteria that synthesize laccases are part of the phyla Firmicutes (B. pumilus, B. subtilis, B. licheniformis), Cyanobacteria (Oscillatoria boryana), Proteobacteria (Escherichia coli, Pseudomonas syringae, Azospirillum lipoferum, Sinorhizobium meliloti, Marinomonas mediterranea), Actinobacteria (Streptomyces coelicolor, S.lavendulae, S. griseus), Aquificae, Deinococcus-Thermus (Thermus thermophilus), Archaea (Haloferax volcanii), and several human pathogens $[7,9,10]$. The synthesis of bacterial laccases can be intracellular or extracellular, occurs in the exponential growth phase, and is induced by the presence of a specific substrate. Bacterial laccases appear to play a role in sporulation, pigmentation, resistance to stressors, and homeostasis [7].

\section{Microorganisms producing laccases}

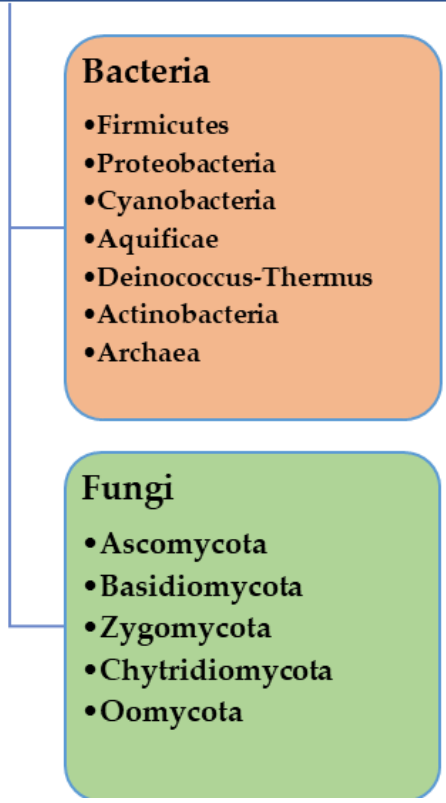

Figure 2. Phyla of micro-organisms producing laccases (authors creation).

\subsubsection{Fungal Laccases}

Fungal laccases are best known for their property of breaking down lignocellulosic material; in this way, they are involved in the biogeochemical cycle of carbon. Fungal laccases act on phenolic compounds, aromatic amines, PAHs, drugs, synthetic dyes, and other substrates [11]. Like bacterial laccases, laccases of fungal origin are involved in the mechanisms of cell protection, sporogenesis, pigmentation, pathogenicity, and in the degradation of the lignocellulosic substrate. Fungal laccases usually have a higher redox potential than in the case of bacteria, with values of approximately $800 \mathrm{mV}$ vs. NHE, and are mainly synthesized by fungi included in the phyla of Ascomycota, Basidiomycota, Chytridiomycota, Zygomycota and Oomycota. Laccase-producing fungi are also involved in litter decomposition and in the humification process. Among the best-known fungal species that synthesize laccases are the Basidiomycetes Agaricus bisporus, P. ostreatus, Lentinula edodes, Ganoderma sp., Phlebia radiate, Trametes versicolor, and the Ascomycetes Trichoderma sp., Chaetomium thermophilum, Theiophora terrestris [1,7,12]. 


\subsection{Structure and Mechanism of Laccases}

\subsubsection{Structure}

The catalytic core of most laccases contains four copper atoms involved in redox processes, which are classified into three types of structures (Figure 3): type 1 (T1), paramagnetic "blue" copper; type 2, paramagnetic "non-blue" copper (T2); and type 3 (T3), the diamagnetic spin-coupled center $[8,13]$. These three types of copper atoms differ in the amino acids to which they bind and in $\mathrm{UV} /$ visible and electronic paramagnetic resonance (EPR) absorption spectra [8,14-20].

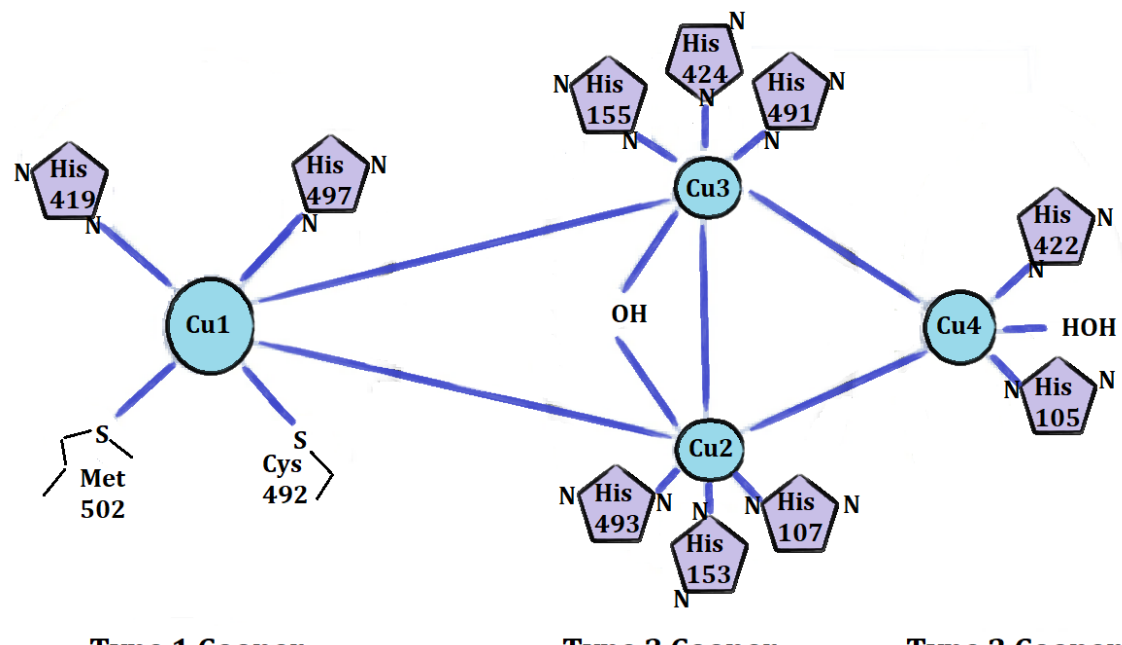

Type 1 Cooper

Type 3 Cooper

Type 2 Cooper

Figure 3. Structure of the active site of laccases (modified from [9]).

\subsubsection{Mechanism of Action}

Laccases catalyze the oxidation reaction of the substrate (phenolic and aromatic compounds, aliphatic amines, and inorganic cations), coupled with the reduction reaction of one molecule of oxygen to two molecules of water. This process takes place in three stages: 1. T1 copper is reduced by receiving an electron from the oxidized substrate; 2 . T1 copper transfers the received electron to the T2-T3 center; and 3. The formation of two water molecules by reducing the oxygen molecule $[3,21,22]$.

The action of the laccases on the substrate is performed by means of the copper cluster from the active site, and can be described schematically by one of the mechanisms in Figure 4. The simplest case is when the enzyme directly catalyzes the oxidation of substrates when they have the appropriate redox potential. If this direct reaction cannot take place, the oxidation of the substrate can occur through a chemical mediator. This system, known as the "laccase-mediator-system", is found in organic syntheses and in the biotechnological processes of degradation of some compounds [22].
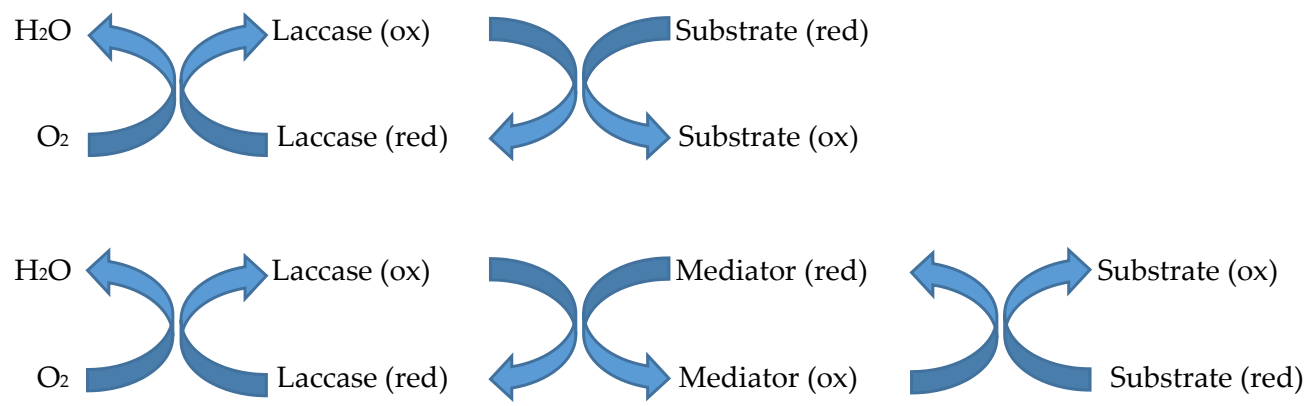

Figure 4. Mechanism of action of laccases (modified from [22]). ox-oxidized state; redreduced state. 


\subsection{Microbial Biosynthesis of Laccases}

Isolation of laccase-producing micro-organisms is performed from various natural substrates such as decayed wood, tree barks, and others, using a spread-plate or streakplate technique. The most productive colonies are selected using screening methods that use chromogenic substrates such as guaiacol. After laboratory testing, the composition of the culture medium (especially carbon and nitrogen sources, trace elements, and inducers), $\mathrm{pH}$, temperature, dissolved oxygen concentration, and agitation should be determined (Figure 5). Due to the relatively high costs, various agricultural by-products such as lignocellulosic substrates (sawdust, wheat bran, rice straw, corn stover, and other cereal waste) have recently been used for the biosynthesis of laccases. Various studies have shown that laccase synthesis occurs at the end of the exponential phase and in the stationary growth phase [23].

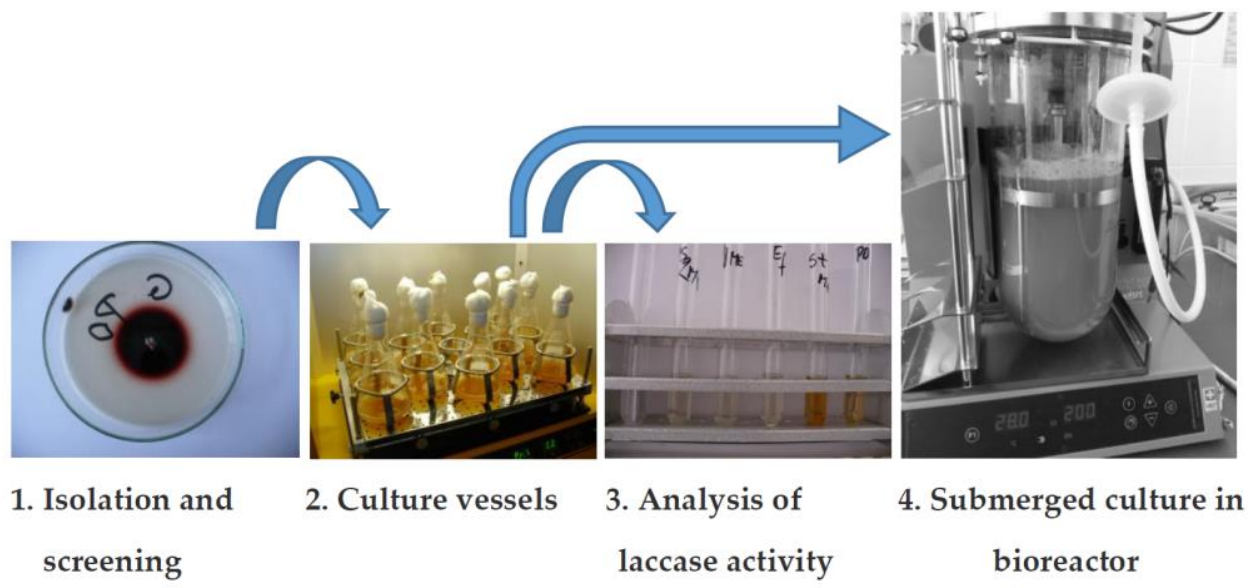

Figure 5. The stages of the biosynthesis process of laccases (authors creation).

\subsection{Immobilization of Laccases}

Due to the high costs and the rather low stability of laccases, in recent times, a large number of studies have been conducted regarding the immobilization of this enzyme on different supports. The advantages of the immobilization of laccases refer especially to its reusability; the increase in storage, $\mathrm{pH}$, and thermal stability; and the improvement of its resistance to the action of inhibitors [24,25]. For the immobilization of laccases, different types of substrate have been studied, namely inorganic, organic, hybrid and composite materials. When choosing these supports, it should be considered that the copper atoms in the catalytic site of laccases may form chelates with support groups, and may destabilize the immobilized enzyme and the catalytic activity $[25,26]$. Various immobilization techniques have been applied such as adsorption, inclusion or entrapment, microencapsulation, cross-linking, and covalent bonding [26,27]. Recently, in the circular economy, the use of cheap, biodegradable materials, such as agro-industrial by-products, as supports for laccase immobilization has been studied. Materials including coconut fiber, eggshell, peach stone, pistachio shell, chicken feathers, spent grain, sugar mill bagasse, and others have some advantages that make them interesting and competitive (low cost, non-toxicity, compatibility with the environment) while being easy to procure and safe, as well as reducing the disposal problems of some waste [27].

Currently, considering cost efficiency, and the applicability at the highest scale (pilot and industrial), one of the best immobilization methods could be the use of cheap supports such as residues and by-products generated from agriculture and household waste, which are cheap, environmentally friendly, and non-toxic. Recent studies have shown good stability of the enzyme, a variety of fields of application, and decreasing disposal problems for these residues.

In this review, we present a comprehensive summary of the applications of laccases to reduce environmental pollution. First, we present a general overview of the impor- 
tance of laccase for the environment and industry, starting with the sources of laccases (plant, bacterial and fungal laccases), the structure and mechanism of laccases, microbial biosynthesis, and the immobilization of laccases. Second, we continue with an overview of agro-waste treatment by laccases wherein we observe the importance of laccases for the biodisponibilization of substrates and the biodegradation of agro-industrial byproducts. Next, we continue with three chapters regarding the degradation of xenobiotic compounds, dyes, and pharmaceutical products. Our aim is to highlight the potential of laccases in solving the problem of accelerated pollutants of the environment. Finally, in the concluding chapter, we present our perspectives on how to further expand the application of laccases in connection with future environmental pollutants.

\section{Agro-Waste Treatment by Laccase}

Lignocellulosic biomass (LB), such as agro-waste and forestry, is the most abundant and economical renewable feedstock in the world that can be converted into biofuel in a sustainable way [28]. Various chemical, thermochemical, and biological technologies were proposed for the conversion of LB to energy [29]. LB consists of three principal componentscellulose, hemicellulose, and lignin - and its biodegradability is highly affected by its composition [30]. Fermentable sugars of biomass carbohydrates necessary for fermentation, such as cellulose and hemicellulose, are trapped inside the cross-linking structure of lignocellulose. Consequently, pretreatment of biomass is always required [31]. In recent years, physical, chemical, biological and physical-chemical pretreatment methods have been explored in order to remove the combination of lignin and hemicellulose and increase the available contact area between enzymes and cellulose, as shown in Figure 6.

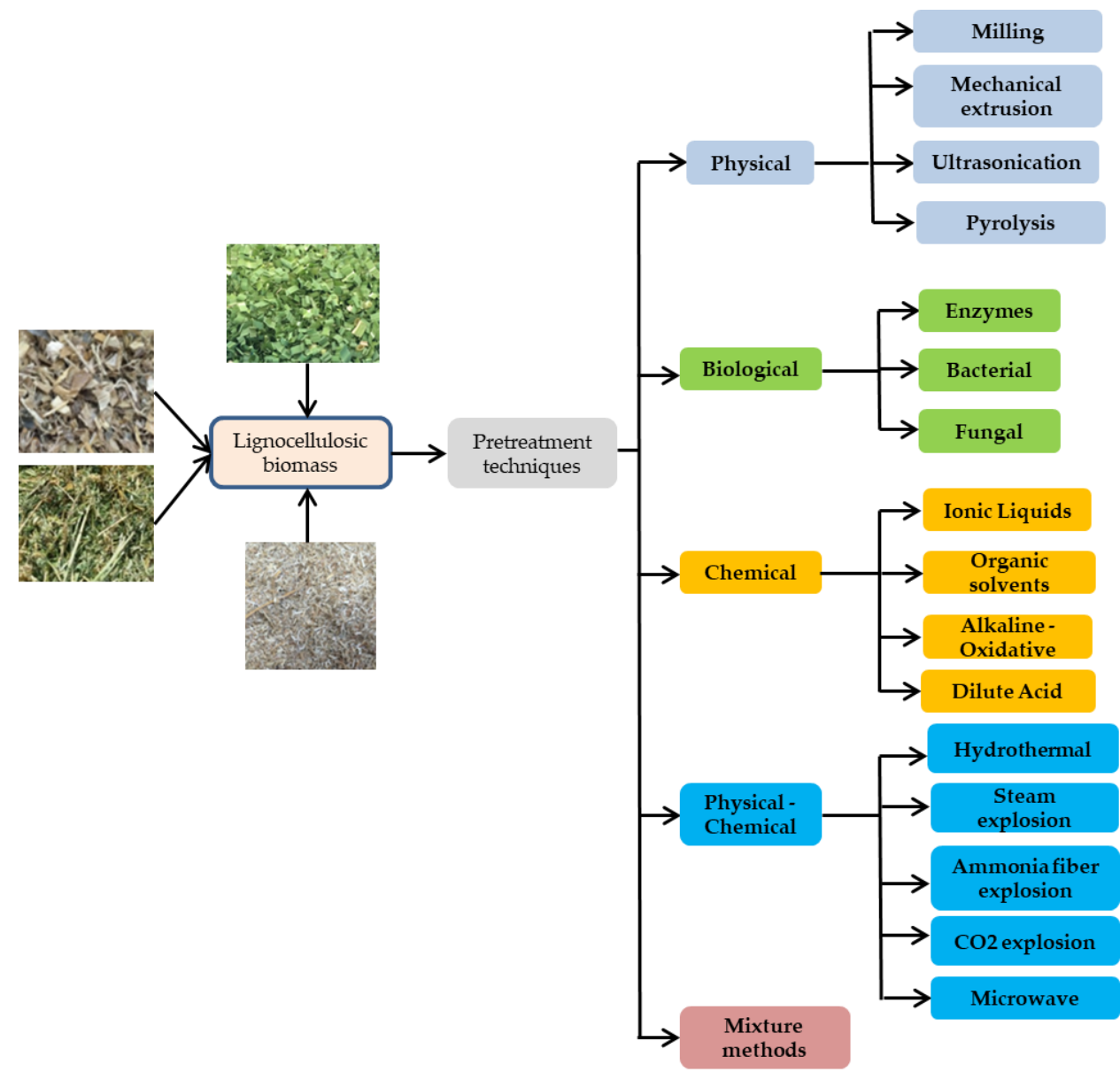

Figure 6. Lignocellulosic biomass pretreatment techniques (based on [32-34]). 
The pretreatment techniques are concentrated on the improvement of the hydrolysis process by altering the polymeric molecules into monomers [35-38]. LB pretreatment represents the main stage for the degradation of its three components and their further conversion to bioenergy with high efficiency [39]. In this context, research on the sustainable pretreatment of lignocellulosic biomass has gained great importance [36]. The suitable pretreatment method is chosen depending on the type of feedstock used. A biological pretreatment applied to lignocellulosic substrate proved to be an economical method that does not need additional energy. Through this pretreatment the inhibitor generation for biofuel production is very low, thus being an environmental friendly method [36,40].

Biological pretreatment consists of the action of bacteria, fungi and enzymes, which degrade the lignocellulosic biomass (Figure 7). White-, brown- and soft-rot fungi are the most-used for the biomass delignification process. It was discovered that white-rot fungi are the most efficient among all fungal types. The best-known oxidative enzymes synthesized in white-rot fungi that are responsible for lignin biodegradation are laccase, lignin peroxidase and manganese peroxidase, the former being the main enzyme involved [36,41,42]. Laccases are enzymes with copper in their active site that catalyze the oxidation reaction of phenolic components in lignin polymers [43]. The laccase enzyme has an essential contribution in lignin decomposition that enhances the yield of the two successive processes: hydrolysis and fermentation [44].

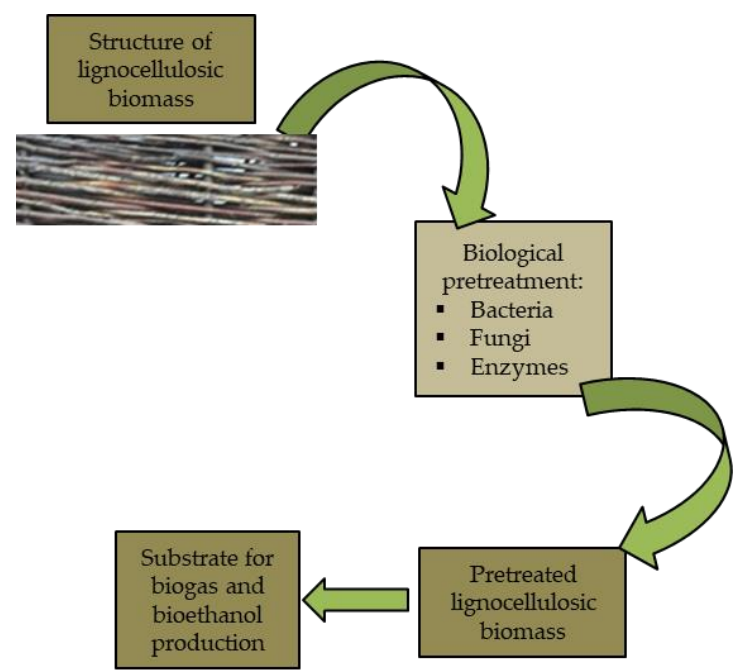

Figure 7. Biological pretreatment of LB for biogas and bioethanol production (modified from [43]).

Furthermore, the enzymatic pretreatment method of LB presents some advantages, such as: quite a low reaction time, low concentrations of nutrients in the substrate for enzymatic reactions, and the fact that it does not require costly plants. On the other hand, the weakness of this method is the high price of enzymes, which continues to be a provocation from an economic point of view [32].

In the literature, much research has been conducted regarding the efficiency of the laccase in the degradation of lignin from lignocellulosic biomass used for biofuel production, especially for biogas and bioethanol.

For example, Jin et al. [45] investigated, in their study, the biological pretreatment (enzyme) and solid-state anaerobic fermentation of wheat straw under different $\mathrm{C} / \mathrm{N}$ ratios. They used cellulase and laccase enzymes, which were purchased from a biotech company. Their results showed that the main components of the tested feedstock were significantly decomposed after enzyme treatment with degradation at $37.47 \%$ for cellulose, $46.96 \%$ for hemicellulose, and $14.05 \%$ for lignin. Additionally, solid-state anaerobic digestion with a $\mathrm{C} / \mathrm{N}$ ratio of 25 , and 30 days of digestion, led to more lignocellulose decomposition (aprox. $74.20 \%$ ) and more biogas production (aprox. $77.59 \mathrm{~L} / \mathrm{kg}$ volatile solid). 
Schroyen et al. [46] tested the corn stover pretreatment with laccase, manganese peroxidase, and versatile peroxidase for biogas production and various incubation periods: 0,6 and $24 \mathrm{~h}$. The authors concluded that the lignin decomposition by laccase pretreatment resulted in an enhancement of methane generation by $25 \%$, whereas peroxidase pretreatment increased methane generation by $17 \%$.

In another study, in 2017, Schroyen et al. [47] investigated the effect of higher concentrations $(0,100,500,1000$ and $2000 \mathrm{mg} / \mathrm{L})$ of different phenolic compounds on the action of lignin-decomposing enzymes and on biogas generation by anaerobic fermentation of LB (hemp straw and miscanthus). The authors analyzed the link of laccase and versatile peroxidase separately with the phenolic substances. The study results showed that the laccase pretreatment detoxified the feedstock efficiently, whereas versatile peroxidase was inhibited by $100 \mathrm{mg} / \mathrm{L}$ of each of the specific phenolic compounds.

In 2018, Wyman et al. [48] analyzed the feasibility of producing enzymes and biogas from corn stover, by using a physical-biological pretreatment followed by an anaerobic fermentation process. Three fungal strains (Pleurotus eryngii, P. ostreatus and T. versicolor) and two particle sizes (the small size was smaller than $4.5 \mathrm{~mm}$, and the large size had values of less than $9.0 \mathrm{~mm}$ ) of LB were compared. The results showed that the highest laccase activity was reached for the P. eryngii strain at day 12 of fungal pretreatment for small particle dimensions. Regarding the biogas production, P. eryngii showed an increase of 19\% after 30 days of treatment for small particle sizes compared with raw corn stover.

The authors, Yadav and Vivekanand [49] studied the ability of C. globosporum to breakdown the lignin coating in wheat and pearl millet straw. The results presented by the authors showed an increase of $124 \%$ and $91 \%$ in reducing sugar release and an enhancement of $43 \%$ and $41 \%$ in lignin degradation for wheat and pearl millet straw.

In another paper, Yadav M. et al. continued their research [50], and tested the isolated fungal strain of C. globosporum for biological pretreatment of wheat and pearl millet straw to improve biogas yield. The efficiency of the fungal strain was verified by assessing laccase activity in submerged culture. Optimized treatment conditions were a temperature of $36{ }^{\circ} \mathrm{C}, 31$ days retention time, and an $81 \%$ moisture content. The conclusions showed that after biological pretreatment with C.globosporum under improved conditions, the content of lignin decreased for wheat straw by $45 \%$, whilst for pearl millet straw, the lignin content decreased by $48 \%$. The biological pretreatment resulted in a 31\% enhancement in biogas yield for wheat straw, and a $46 \%$ higher yield for pearl millet straw in comparison to untreated samples.

Moreover, in 2020, biological pretreatment of LB consisting of wheat and pearl millet straw was also performed by Yadav and Vivekanand [51] by using the selected fungal strain of Curvularia lunata, with an improvement in treatment parameters, namely: treatment period (14 days, 28 days and 42 days), temperature $\left(28{ }^{\circ} \mathrm{C}, 32{ }^{\circ} \mathrm{C}\right.$ and $\left.36^{\circ} \mathrm{C}\right)$ and moisture content $(65 \%, 75 \%$ and $85 \%)$. The ability of fungal strains to synthesize laccase was analyzed by applying a colorimetric test with guaiacol as substrate for the enzymatic reaction. The authors reported remarkable growth in the biogas volume (19\% and $28 \%)$ and biomethane ( $23 \%$ and $39 \%$ ) yield for both tested substrates (wheat and pearl millet straw) as compared to unprocessed samples.

In their study, Fithri et al. [52] isolated and evaluated the activity of fungal laccase found in the fungi of oil palm empty fruit bunch. Fungal laccase was tested for the biological treatment of two agricultural wastes (rice straw and corn cob). Additionally, authors used a scanning electron microscope (SEM) to observe the structure of cereal agriculture waste fibers in both treated and untreated samples. SEM images of rice straw and corn cob waste after being treated with laccase indicated the presence of degradation activity.

Cai et al. [53], conducted a comprehensive review regarding the effects of lignocellulosic biomass pretreatment methods (physical, chemical, biological and combined pretreatment) on methane production. The authors concluded that combining biological pretreatment with physical or chemical pretreatment is the most promising pretreatment route. 
In the same way, Bruni et al. [54] identified different methods to enhance the biomethane production of biofibers from digested manure. They investigated several pretreatment methods, such as: physical, chemical, biological (laccase and a mixture of cellulases and hemicellulases, and partial aerobic microbial conversion, were used), steam treatment with a catalyst, and combination of biological and steam treatments. In conclusions, the authors reported that a $66 \%$ increase in methane production was obtained for chemical treatment and a $26 \%$ increase in methane production was reached in the case of steam treatment. In addition, the association of steam treatment and enzyme laccase Novozym 51,003 pretreatment of manure fiber increased the methane yield by $34 \%$.

Sijinamanoj et al. [55] used agricultural residues consisting of paddy straw, sugarcane bagasse, and coconut husk as substrates for biodegradation by Aspergillus nomius and Trichoderma harzianum isolated from gut of the termite, Odontotermes obesus and fungus comb in the termite mound, respectively. Thus, fungal pretreatment of lignocellulosic biomass for 45 days showed that Aspergillus nomius and Trichoderma harzianum degraded $84.4 \%$ and $81.66 \%$ of hemicelluloses, $8.16 \%$ and $93.75 \%$ of cellulose, and $52.59 \%$ and $65 \%$ of lignin, respectively.

In another study, Albornoz et al. [56] found that the fungal treatment of wheat straw with Pleurotus ostreatus, was the most favorable treatment condition to produce laccase and biogas.

Mustafa et al. [57] conducted a study wherein rice straw was subjected to fungal pretreatment using P. ostreatus and T. reesei, to enhance its biodegradability and methane yield through solid-state fermentation. The authors reported that the pretreatment with $P$. ostreatus was most effective at $75 \%$ moisture content and a 20 day incubation period, resulting in $33.4 \%$ lignin removal.

Other studies using a fungal delignification pretreatment of LB were performed for bioethanol generation. For example, Salvachua et al. [58] applied a combined pretreatment (fungal pretreatment and mild alkali treatment) to wheat straw for ethanol production. The reported results showed that the glucose production, after 21 days of pretreatment, obtained $69 \%$ and $66 \%$ of cellulose accessible in the wheat straw, with an ethanol production of $62 \%$ in the two cases, with Poria subvermispora and Irpex lacteus.

Chang et al. [59] conducted an experiment in order to increase the lignin degradation and saccharification yield of rice straw, testing laccase (T. versicolor) in the presence of ionic liquid. The authors noted that the maximum cellulose hydrolysis was $40.96 \%$ when using a combined pretreatment with laccase + TritonX-100, and 38.24\% for laccase + 1-Allyl-3methylimidazolium chloride, after $72 \mathrm{~h}$ of enzymatic saccharification.

In their work, Moreno et al. [60] evaluated the use of MetZyme, a new bacterial laccase for improving the property of hydrolysis and fermentation of steam-exploded wheat straw for ethanol production. The reported results showed that the combination of alkali extraction and laccase treatment led to an increase of $21 \%$ and $30 \%$ in the glucose and xylose concentrations in the hydrolysate.

Liu et al., in their study, assessed the efficiency of the alkaline fungal laccase PIE5 $(\mathrm{pH} 8.5)$ in the lignin degradation and detoxification of alkali-pretreated corncob, to obtain bioethanol [61]. The authors compared fungal laccase PIE5 performance with that of the neutral fungal laccase $\mathrm{rLcc} 9$ ( $\mathrm{pH}$ 6.5). Simultaneously, a classical acidic fungal laccase rLacA ( $\mathrm{pH}$ 4.0) from Trametes hirsuta AH28-2 was used as an independent control. The results showed that the best values for the laccases' activity were recorded in the following order regarding the total phenol concentration decrease $(0.18,0.36$, and $0.67 \mathrm{~g} / \mathrm{L})$, ethanol concentration increase $(8.02,7.51$, and $7.31 \mathrm{~g} / \mathrm{L})$, and ethanol production $(1.34,0.94$, and $0.91 \mathrm{~g} / \mathrm{L}$ hour): rLacA > rLcc9 > PIE5.

For easy understanding and an overview of the elements mentioned above, we present in Table 1, the synthetic information regarding some substrates, enzymes and pretreatment conditions. 
Table 1. Enzyme types used in LB pretreatment [45-52,55-61].

\begin{tabular}{|c|c|c|c|c|}
\hline Substrate & Enzymes & Pretreatment Conditions & Micro-organism & References \\
\hline Wheat straw & Cellulase and laccase & $\begin{array}{l}\text { Solid-state anaerobic digestion } \\
\text { with a } \mathrm{C} / \mathrm{N} \text { ratio of } 25 \text { and } 30 \\
\text { days digestion }\end{array}$ & - & [45] \\
\hline \multirow{2}{*}{ Corn stover } & $\begin{array}{c}\text { Laccase, manganese } \\
\text { peroxidase and versatile } \\
\text { peroxidase }\end{array}$ & Anaerobic fermentation & \multirow{2}{*}{$\begin{array}{l}\text { Pleurotus eryngii, } \\
\text { P. ostreatus and } T . \\
\text { versicolor }\end{array}$} & \multirow{2}{*}[46,48]{} \\
\hline & Laccase & $\begin{array}{l}\text { Physical-biological } \\
\text { pretreatment followed by an } \\
\text { anaerobic fermentation process }\end{array}$ & & \\
\hline $\begin{array}{l}\text { Hemp straw and } \\
\text { miscanthus }\end{array}$ & & Anaerobic fermentation & - & {$[47]$} \\
\hline \multirow[b]{2}{*}{$\begin{array}{l}\text { Wheat and pearl millet } \\
\text { straw }\end{array}$} & \multirow[b]{2}{*}{ Laccase } & Biological pretreatment & C. globosporum & {$[49,50]$} \\
\hline & & $\begin{array}{l}\text { Treatment parameters, namely: } \\
\text { treatment period ( } 14 \text { days, } 28 \\
\text { days and } 42 \text { days), } \\
\text { temperature }\left(28^{\circ} \mathrm{C}, 32{ }^{\circ} \mathrm{C} \text { and }\right. \\
\left.36{ }^{\circ} \mathrm{C}\right) \text {, and moisture content } \\
(65 \%, 75 \% \text { and } 85 \%)\end{array}$ & Curvularia lunata & {$[51]$} \\
\hline Rice straw and corn cob & Laccase & $\begin{array}{l}\text { Biological treatment, } \\
\text { solid-state fermentation }\end{array}$ & P. ostreatus and T. reesei & {$[52,57]$} \\
\hline $\begin{array}{c}\text { Paddy straw, sugarcane } \\
\text { bagasse, and coconut } \\
\text { husk }\end{array}$ & - & - & $\begin{array}{l}\text { Aspergillus nomius and } \\
\text { Trichoderma harzianum, } \\
\text { Odontotermes obesus }\end{array}$ & [55] \\
\hline \multirow{3}{*}{ Wheat straw } & \multirow{3}{*}{$\begin{array}{l}\text { Laccase, } \\
\text { glucose }\end{array}$} & $\begin{array}{l}\text { Anaerobic digestion during } \\
30 \text { days }\end{array}$ & Pleurotus ostreatus & {$[56,60]$} \\
\hline & & $\begin{array}{l}\text { Fungal pretreatment and mild } \\
\text { alkali treatment }\end{array}$ & $\begin{array}{l}\text { Poria subvermispora and } \\
\text { Irpex lacteus }\end{array}$ & [58] \\
\hline & & $\begin{array}{c}\text { Combined pretreatment with } \\
\text { laccase }+ \text { TritonX-100 and } \\
38.24 \% \text { for laccase }+ \\
\text { 1-Allyl-3-methylimidazolium } \\
\text { chloride }\end{array}$ & T. versicolor & [59] \\
\hline Corncob & Alkaline fungal laccase & - & Trametes hirsuta & {$[61]$} \\
\hline
\end{tabular}

However, in the literature, studies show that the association of physical, chemical and physical-chemical pretreatment methods with biological treatment applied to LB increases lignin removal and enzymatic digestibility [62-65].

\section{Degradation of Dyes}

In recent years, laccases have shown high significance in industrial and environmental use, mainly in dye decolorization. According to studies, synthetic paints are considered one of the world's biggest pollutants today [66].

Dyes are often used in the industrial sector, especially in the food, pharmaceutical, textile, paper, and chemical industries [67]. According to World Health Organization, the textile industry is one of the major contributors (17-20\%) to water pollution, with azo dyes ( $\mathrm{N}=$ Ngroups) comprising $80 \%$ of the total amount [68]. Considering the chemical compounds and the utility, dyes are divided into several categories, such as: triphenylmethane, azo, polymers, heterocyclics, and anthraquinones, although the dyes are made up of a group of atoms called chromophores which are capable of coloring [69]. A significant amount of dye-almost $10-15 \%$ - is expected to be discharged into wastewater during the production process. 
Azo dyes are the most important class of dye utilized in the industrial sector, and pass-through municipal wastewater treatment plants nearly unmodified because of their resistance to aerobic treatment. In anaerobiosis, azo dyes are cleaved by bacteria and fungi to form aromatic amines, which have a carcinogenic effect on the population [70].

Because of the high costs involved in the disposal of dyes, industries face the problem of treating industrial effluent containing dyes because they are made up of different groups of chemicals [71]. The harmful effect is observed in the negative impact on different biotic environments-from phytoplankton, aquatic organisms, zooplankton-but also on human beings [72]. In human organisms, the presence of harmful dyes contained in the effluent discharged into the environment can cause allergies, dermatitis, respiratory disease and systemic disorders [73].

Existing decolorization techniques may be useful, but they have the disadvantage of time and price requirements. Different treatment techniques have been used for the decomposition of dyes in wastewater. These consist of different physical, chemical, and biological decomposition methods (Figure 8) [74]. Physical and chemical methods generate great quantities of iodine, aromatic amines, and secondary products [71]; meanwhile, biological processes, also called bioremediation, are clean, efficient, and environmentally friendly, involving aerobic and anaerobic decomposition produced by bacteria and fungi, which are usually extremophiles that generate diverse enzymes [75].

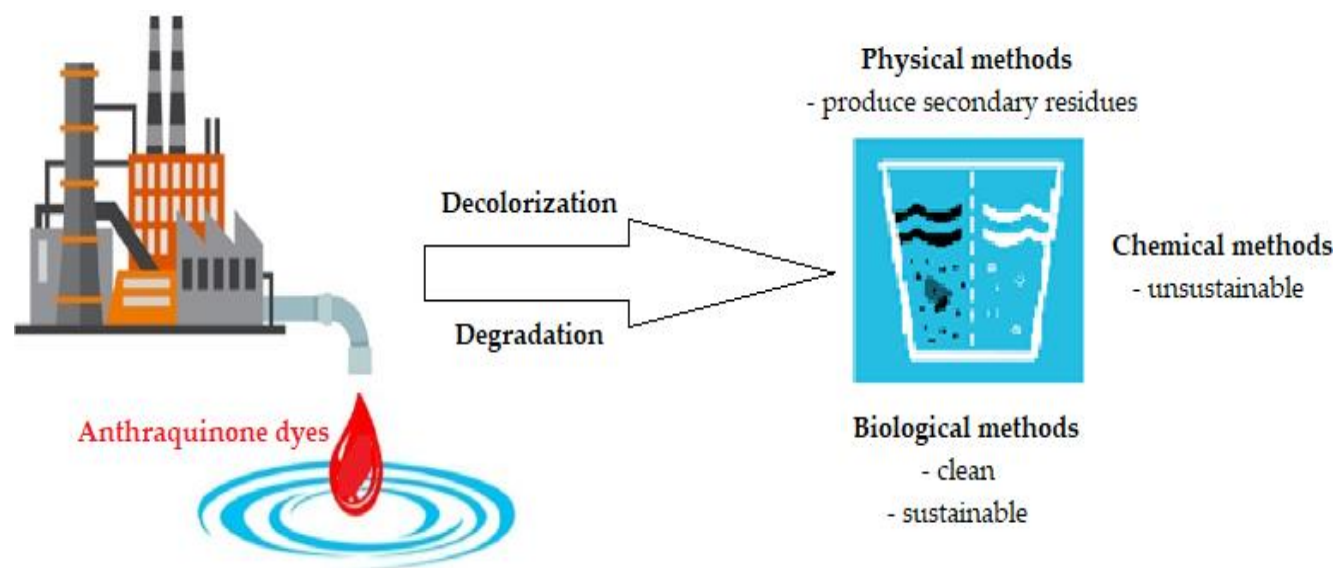

Figure 8. Existing methods of decolorization (modified from [76]).

Bioremediation is a successful process in the treatment of colorants present in wastewater, due to its profitability, the lack of chemical by-products, and green technology to mitigate the negative effects of industrial contamination [77]. During this process, microbial enzymes can remove toxic constituents, and the ecological effect of these textile dyes can be minimized [78].

In recent years, many industries have focused on the enzymatic approach to developing green technology, especially due to the deficit of physical-chemical methods, increasing environmental issues, legislative limitations, and improvement of the scientific knowledge.

The oxidizing enzymes in white-rot fungi are well known, because they act on synthetic dyes. This kind of enzyme represent an important source of dye degradation [79,80]. In enzymatic decomposition, azoreductases, peroxidases and phenol oxidases are capable of biodegrading dyes, but in some ways, these enzymes reduce their biodegradation performance. In particular, laccase-assisted reactions are the subject of extensive research because they are environmentally friendly and have great potential applications. Laccases require only oxygen as a substrate, and they produce water as single by-product [81].

Due to the field of interest, numerous studies have been conducted to remove dyes from different industries, the most relevant being presented as follows:

Jamal M. et al. [73] studied how laccase-producing bacteria have significantly influenced the decolorization of textile azo dyes. In this article, two different strains of bacteria 
were isolated from Western Ghats. Laccases have been produced from $B$. cereus and $P$. parafulva by submerged fermentation. The free and immobilized laccases decolorized the three azo dyes T-blue, yellow GR and orange 3R. Decolorization was confirmed by the data obtained through UV-vis and FTIR spectroscopy, which demonstrated the modification of peaks. As a result of the bacterial decolorization effect, it was concluded that the production of free laccase and the production of immobilized laccase were highly effective against the degradation of azo dyes. Beyond that, $P$. parafulva produced a higher degree of decolorization than $B$. cereus for all dyes. The removal efficiency for the three azo dyes was between $89.21-91.69 \%$.

In 2021, Ashutosh Y. et al. [80] studied the possibility of decolorization in the textile dye industry in the presence of laccases. The authors improved the biodegradation of the Remazol Brilliant Blue R (RBBR) dye using laccase derived from Arthrographis kalrae (Figure 9).

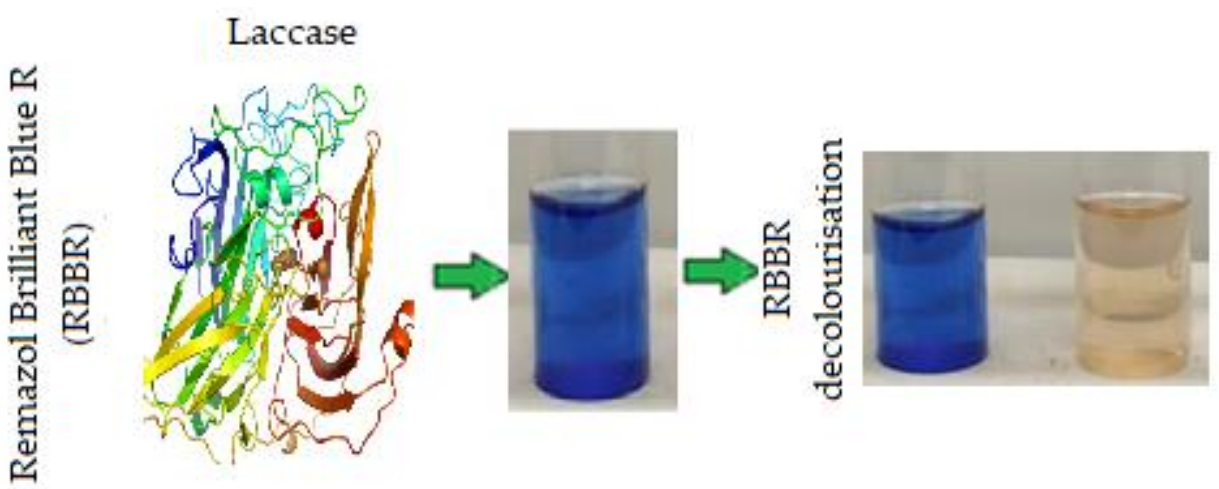

Figure 9. Biodegradation of RBBR (modified from [80]).

The rate of decolorization was influenced by enzyme concentration, $\mathrm{pH}$, time of action, and dye concentration. The process was optimized by improving the decolorization of BBD dye (97.18\%), which was demonstrated by FTIR and UV-Vis spectroscopy. Moreover, compared with unprocessed samples, the laccase-treated dye sample indicated a lower phyto- and cyto-toxic effect on Allium cepa L. [80].

In another study, Tauber M.M. et al. [82] investigated the decomposition of azo dyes by oxidative processes using treatment with laccase and ultrasound, applied alone or combined. For this research, laccase obtained from T. modesta was used. The authors showed that laccase reduces Acid Orange and also Direct Blue dyes within 1 to $5 \mathrm{~h}$, but it was ineffective in the case of reactive dyes. The secondary ultrasound treatment applied degraded the evaluated dyes ( 3 to $15 \mathrm{~h}$ ). It was demonstrated, for the first time, that treating the effluents containing dyes using laccase and ultrasound the same time can save more time and also more energy, without compromising the laccase efficiency.

Indigo dyes are blue-colored organic compounds isolated from Indigofera suffructicosa Mill., Indigo feratinctoria L., Polygonum tinctorium or Isatis tinctoria L. extract. Indigo, but also its derivatives, play an important role in several fields, such as food industry, textiles or cosmetics, due to their color; however, they are extremely dangerous for humans. It was shown that the first stage in their degradation is electrochemical oxidation, followed by a nucleophilic attack [83].

Younes and Sayadi in 2013 [84], showed that the enzymatic decomposition of indigo carmine dye using laccase obtained from Scytalidium thermophillum achieved a 98\% decolorization rate after one day of treatment. These results were also demonstrated by Campos et al. [83]. They found that the process of indigo decomposition was more efficient using the laccase isolated from the fungus T. hirsuta than using the laccase isolated from the bacterium $S$. rolfsii.

In another study, Abadulla E. et al. [85] studied the process of decolorization and detoxification of textile dyes using a laccase isolated from the fungal strain T. hirsuta. They 
reported that this laccase was capable of degrading triarylmethane, indigoid, azo, and anthraquinonic dyes. Treatment using an immobilized laccase reduces dyes' toxicity by up to $80 \%$. A study conducted by Rui M.F. et al. [86] demonstrated the possibility of improving the enzymatic degradation of textile dyes. The authors proposed the innovative use of ionic liquids (ILs) to enhance the decomposition of indigo carmine (IC) dye using laccase (Figure 10).

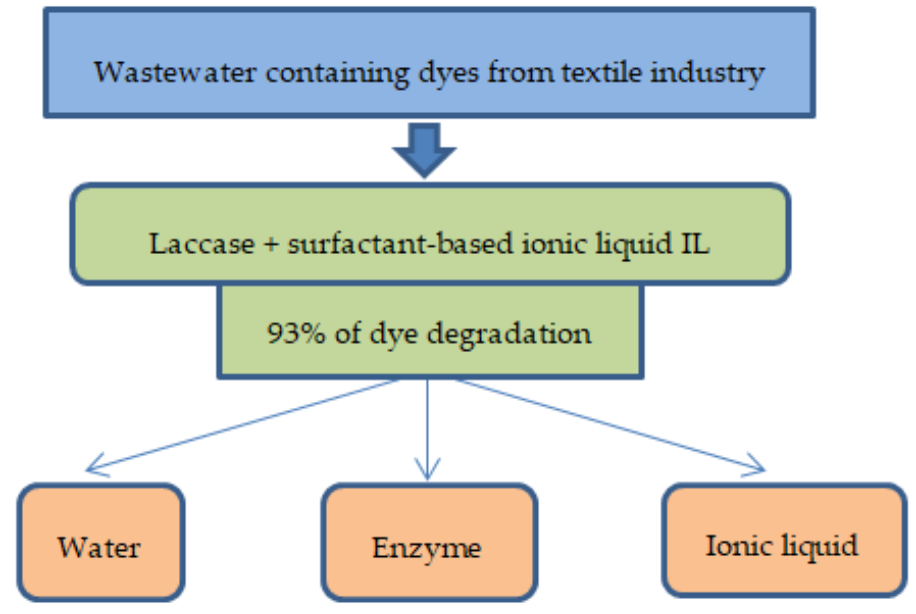

Figure 10. Degradation of dyes using surfactant ionic liquids (ILs) (modified from [86]).

It has been shown that the utilization of the decyltrimethylammonium bromide$\left[\mathrm{N}_{10111}\right] \mathrm{Br}$ is optimal for enzymatic action on dyes. It was significant that in $0.5 \mathrm{~h}$ a color removal percentage of $82 \%$ was achieved, compared to $6 \%$ removal when IL was not been used. After one day of treatment under the same conditions, a decolorization rate of $93 \%$ was obtained [86].

Laccase-functionalized micromotors have been investigated by Uygun M. et al. [87]. The results show that enzymes on board micromotors have higher stability in their activity without structural damage. In comparison to the free-enzyme approach, in terms of efficiency, reaction time, and convenience of use, the "self-propelling" action of laccasemodified micromotors enhanced the decolorization capacity. The results showed an efficiency of 76-94\% for decolorization treatment when compared with the use of a free enzyme, which achieved a decolorization efficiency of $34 \%$ to $55 \%$.

Laccases are recognized for their ability to degrade synthetic dyes present in wastewater, resulting the less harmful products [67]. Based on studies in the literature, it has been shown that laccases have the ability to breakdown various dyes' structures. In study [88] a removal efficiency of $98.6 \%$ was obtained for indigo dyes. The decolorization efficiency of laccases was also applied in study [89]. In the case of Procyon Red, laccase had a yield of $90 \%$ [90], compared to $100 \%$ in the case of Indole dye [91].

The performance of biodegradation is affected firstly by the group of the organisms that synthesize laccases, and secondly by the staining rates.

\section{Degradation of Xenobiotic Compounds}

\subsection{Basics of Xenobiotic Compounds}

The rapid growth in both population and technology has affected and will affect people's lives whether they want it or not [92]. Most importantly, the increase contributes to global progress and expansion, but at the cost of the environment. Globalization, which is seen mainly as technological progress, represents new substances, products and/or pesticides that are released in the environment; this ultimately has an impact not just on us humans, but on the entire ecosystem [93-95]. Pollution is currently one of the most important topics to be discussed and solved, with the European Union channeling parts of their goals into waste reduction, a circular economy, a clean environment, reducing climate 
change, etc. Since a large part of the pollution is manmade, some of the contaminants cannot be naturally degraded [96].

The most common synthetic compounds are xenobiotics (foreign things in living form) [97], which are widely spread in agriculture, in domestic usage, in the environment, and in industrial activities. To see the impact of xenobiotics on the environment, a series of studies was conducted by scientists, which highlighted the impact of xenobiotics on animals, the environment, and humans.

The 20th century represented an expansion period for humanity; technological progress exploded, and there was an increase in different compounds that were meant to help improve day-to-day life, such as antibiotics, illicit drugs, pesticides, industrial products, dyes, additives, PCPs, etc. (Figure 11). All of these are physicochemical structures that can cause problems should be identified, quantified, and removed [98].

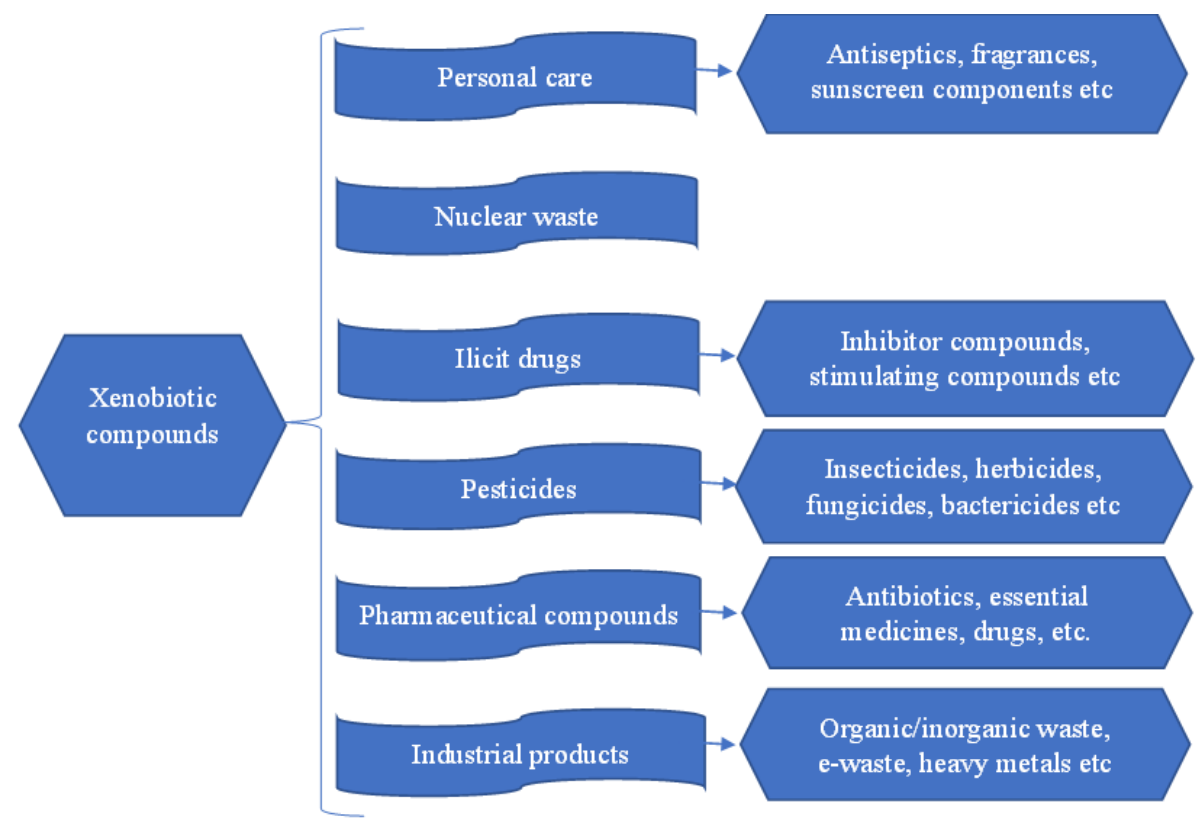

Figure 11. Xenobiotic compounds (modified from [99]).

Due to the threat xenobiotic contamination poses, researchers have studied various treatment methods, both physical and chemical (electrolysis ozonation, filtration, chemical precipitation, coagulation, etc.), for degradation and detoxification; however, not all of these were successful or helpful due to high costs, and the generation of toxic by-products [100]. One method that registered success was bioremediation, which is a biological remediation method that did not register any other products that could be harmful [101,102]. Bioremediation methods are mostly designed by using micro-organisms. Removing xenobiotics form sediments, soil, or water represents the process of obtaining $\mathrm{CO}_{2}$ and $\mathrm{H}_{2} \mathrm{O}$, products that do not cause damage to the environment $[103,104]$. The findings obtained in the research, presented in Table 2, reveal that different types of micro-organisms can degrade xenobiotic compounds. 
Table 2. Microorganism involved in the xenobiotic degradation process [105-112].

\begin{tabular}{ccc}
\hline & Micro-Organisms & \\
\hline Bacteria & Fungi & Yeasts \\
\hline Pseudomonas & Aspergillus & Pichia \\
Alcaligenes & Penicillium & Rhodotorula \\
Cellulosimicrobium & Trichoderma & Candida \\
Microbacterium & Fusarium & Aureobasidium \\
Micrococcus & & Exophiala \\
Methanospirillum & & \\
Aeromonas & & \\
Bacillus & & \\
Sphingobium & & \\
Flavobacterium & \\
Rhodococcus & \\
\hline
\end{tabular}

Although they are efficient, there are some factors such as the ecological characteristics that can influence the degradation process outcome. Additionally, bioremediation studies presented the potential for and capability of microorganism biodegradability when having to deal with a large number of environmental contaminants, all because of the mutagenesis processes [113-116]. In Figure 12, the chemical structures of various xenobiotic compounds are presented.

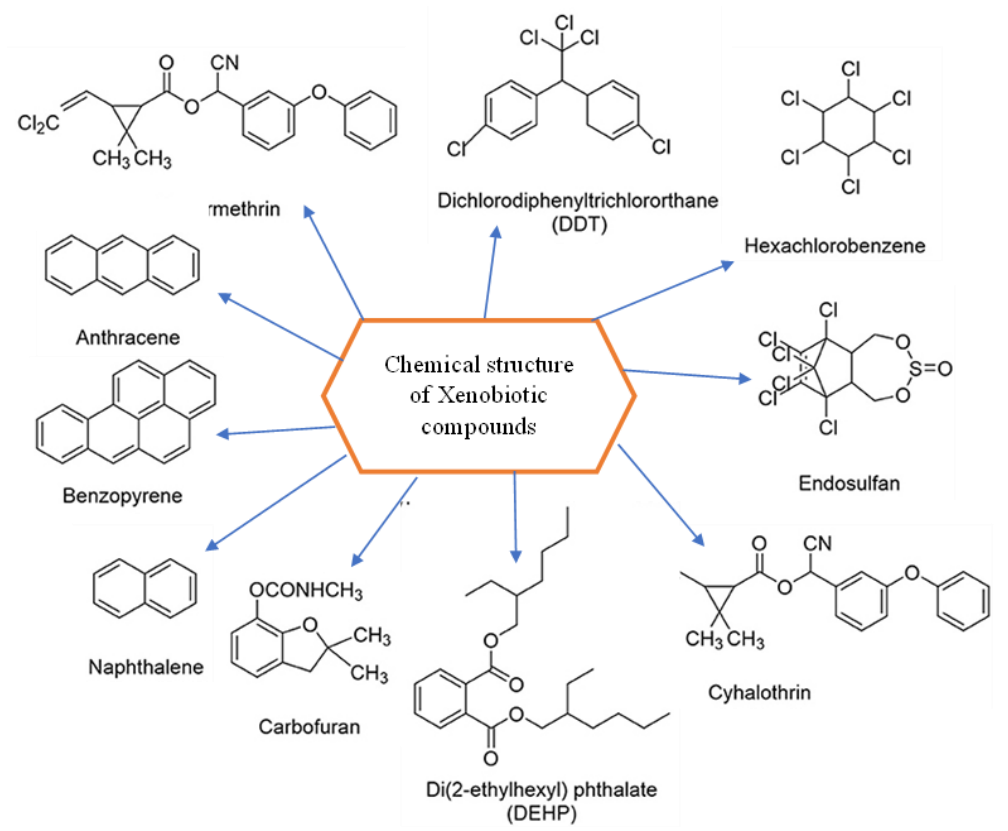

Figure 12. Xenobiotic compounds-chemical structures (selection) (modified from [100]).

A lot of these synthetic compounds have been used in agriculture (pesticides) and insect control programs. One of the pesticides most studied by scientists and considered to be highly toxic is lindane ( $\gamma$-hexachlorocyclohexane) [117-119]. After extensive studies, it was concluded that lindane concentration has an impact not only on immunosuppressive diseases in humans, but also on endocrine disruption, carcinogenicity, mutagenicity, etc. [120,121].

\subsection{Laccase and Xenobiotics}

Laccases' enzymes play an important role in different industries, because they contribute to xenobiotic biodegradation, paper bleaching, etc. [122]. Their ability to oxidize various substrates, and low substrate particularity, provide laccase with the main fac- 
tors needed to perform xenobiotic biodegradation [123]. Even with these, there are some drawbacks when using laccase because, according to studies, they have high costs, poor reusability, loss of enzyme activity and low yields [124]. The use of laccase enzymes was analyzed by scientists in relation to different types of pollutants.

In paper [125] scientists presented an analysis regarding the separation of toxic pollutants from water resources. Their main goal was azo dye removal because of its high toxicity. For this, they used a bacterial laccase synthesized by P. mendocina. The results found through LC-MC analysis revealed that degradation mainly happened through oxidation of azo-hydrazo linkages and phenolic groups. Additionally, it showed that dye degradation happened due to laccase-producing bacteria from MBBR isolation.

Environmental pollution can also be caused by Anthraquinones (AQs) which can be found in personal care products, dyes or even some pharmaceutical products [126]. Although some researchers found that laccase removed 72\% of the AQ dye in 60 min [127], in paper [128], scientists proposed alizarin green, a typical AQ, for testing the biodegradation ability of the immobilized laccase. A laccase immobilized on a metal-organic framework/polyvinyl-alcohol-cryogel as a substrate was studied in relation to wastewater pollution from personal care products, dyes, and pharmaceutical products. The experiments were conducted by preparing and applying metal-organic-framework-based cryogels such as "PVA/Lac, ZIF-67(Co)/PVA/Lac, HKUST-1(Cu)/PVA/Lac, MIL-53(Al)/PVA/Lac, MIL68(Al)/PVA/Lac, MIL-100(Fe)/PVA/Lac, MIL-101(Cr)/PVA/Lac, and MIL-101(Fe)/PVA/ Lac". The metal-organic framework that registered the best result was MIL-68(Al)/PVA/Lac, both for relative laccase activity and for alizarin green removal (95.86\% success rate).

Continuing with environmental pollution in paper [129], the biodegradation of anthracene was analyzed by studying the immobilization of lignin-decomposing enzymelaccase on the surface of rice straw biochar. The immobilization of laccase was $66 \%$, obtained by applying acid treatment on the rice straw biochar to obtain carboxyl. An important parameter for the research, to obtain conclusive data, was operation stability which, in this case, was analyzed for consecutive cycles. Depending on the cycle, the laccase activity registered was different, from no loss in the laccase activity registered in the first cycle to $60 \%$ for the 6th cycle. Their results are consisted with [130] which, just after two cycles, revealed a $50 \%$ loss in laccase activity.

Further research into laccase activity for xenobiotic degradation was conducted using fungi that generate ligninolytic extra-cellular enzymes (Basidiomycetes). According to scientists, white-rot fungi registered a higher efficiency in lignin degradation than other laccases (present in fungi) [131]. Fungi's abilities in laccase activity were constantly observed and analyzed in correlation to lignin decomposition. Thus, it could be observed that it is very important in xenobiotic degradation compounds, one of these being polycyclic aromatic hydrocarbons (PAHs) [132]. Whether we are considering human activity or natural activities, PAHs are among the environmental contaminants. In paper [133] the authors studied different strains from different areas in Sarawak, which presented great laccase activity in culture. The results revealed that Coriolopsis caperata BM-172 produced the highest value for laccase activity $(880 \mathrm{U} / \mathrm{L})$.

Continuing in the same area of xenobiotic degradation, in paper [134], the analysis was focused on pyridine raffinate (organic pollutant) degradation using bacterial laccase. To optimize laccase production, the optimization of carbon and nitrogen sources, $\mathrm{pH}$, time, and temperature were considered. The laccase activity for the samples was measured every $12 \mathrm{~h}$ for 5 days, and determined using a guaiacol assay. The results showed a degradation of pyridine raffinate between $51-59.5 \%$, depending on the values of the optimized parameters.

Further studies using white-rot fungi to degrade organic pollutants were conducted. Only a few researched the fungal of degradation 2,3,7,8-tetrachlorodibenzo-p-dioxin. Just a few ligninolytic fungi can degrade this dioxin, among which we can mention Rigidoporus sp. FMD21. Studies revealed a laccase extraction of $77.4 \%$ of 2,3,7,8-tetrachlorodibenzo-pdioxin in 36 days. In paper [135] authors presented a new degradation mechanism. This is based on 3,4-dichlorophenol, which represents the main metabolite of $2,3,7,8-\mathrm{TCDD}$ 
degradation. Out of six laccase mediators, only violuric acid reached the significance level needed regarding the effect on 2,3,7,8-TCDD degradation by extracellular enzyme extraction. They concluded that Rigidoporus sp. FMD21 produces laccases that can degrade 2,3,7,8-tetrachlorodibenzo-p-dioxin.

Other pollutants that affect both the environment and human health are heavy metals, which can come from various industries (textile, plastics, microelectronics, etc.). Considering this in paper [136], authors describe the study of two heavy metals, $\mathrm{Pb}$ and $\mathrm{Ni}$, on laccase activity in Trametes pubescens. The laccase activity remained stable in solutions containing $\mathrm{Pb}$ and $\mathrm{Ni}$. Additionally, they concluded that the increase in $\mathrm{Pb}$ concentration led to a decrease in laccase activity, while Ni concentration presented an increase in activity for 10 to 25 ppm of $\mathrm{Ni}$.

Another study in PAH degradation in soil was conducted using a laccase mediator system. This was performed using a packed bed reactor. Additionally in this study, as the previous one mentioned, six polycyclic aromatic hydrocarbons were considered for degradation; however, the first step was laccase production by solid-state fermentation. The factors that proved their importance were mediators in the oxidation of PAH. Natural mediators proved to be capable of better results than synthetic ones. The degradation values obtained were $74.8 \%, 71.9 \%, 72.2 \%, 81.8 \%$ and $100 \%$ degradation for fluorene, anthracene, phenanthrene, chrysene and pyrene, while for benzo[a]pyrene, a $96 \%$ degradation was recorded [137].

Another pollutant that has a high resistance to degradation is 2,4-Dinitrophenol (2,4DNP). Hadiseh et al. [138] analyzed the ability of laccase enzymes (laccase complexes with montmorillonite K10 and zeolite) to decompose 2,4-DNP from wastewater and soil. The results presented percentages of $98.5 \%, 98.6 \%$, and $90.4 \%$ removal from soil containing free laccase, laccase-zeolite, and laccase-montmorillonite complexes; for wastewater, the percentages for the removal of pollutants were $99 \%$ and $93.3 \%$, respectively. They concluded that the degradation of 2,4-DNP by applying laccase-zeolite complexes was a success.

Pesticides in agriculture and in household usage has become a widely known practice that, used excessively, can cause environmental pollution influencing the entire ecosystem [139]. As seen in extensive research, some fungal laccases can be used for pesticide degradation, mainly because they do not produce other substances that can be harmful [140]. Continuous studies on pesticide degradation have been conducted, one aiming to characterize the laccase from Tricholoma giganteum AGDR1 in this problem.

$121.056 \mathrm{U} / \mathrm{g}$ of laccase activity was shown by T. giganteum AGDR1 using wheat straw as a substrate for the experiments. The test revealed that T. giganteum AGDR1 contains elements that are xenobiotic, metal responsive and that exhibit heat shock, which could represent that the laccase enzyme is tolerant to inhibitors, organic solvents and metals. Increased laccase activity of Tricholoma giganteum AGDR1 was seen in solid state fermentation. Additionally, it was found that purified laccase contributed significantly to pesticide degradation [140].

Trying to remove pesticides residues so that pollution does not occur is a concern of many. Scientists perform different methods, even combining adsorption and degradation based on biodegradable microporous starch-immobilized laccase (LA-MPS). To obtain good results, LA-MPS was used with mediators for the removal of atrazine and prometryn (herbicide) from water. The results showed that the method proposed can be applied, because the removal recorded was increased by $61 \%$ compared to natural degradation [141].

Organic pollutants are, unfortunately, a factor that contributes to environmental degradation and human health problems. Very harmful for people are polychlorinated biphenyls (PCBs), also mentioned in the Stockholm Convention on persistent organic pollutions [142]. Although there are some strategies in place for PCB removal, scientists conducted a study on the biodegradation of PCBs using fungal strains. The strains used were taken from contaminated soil on a former industrial site and PCB-contaminated sediment [143]. Laccase monitoring and activity was investigated for all 12 strains used in the experiment. Due to the fact that not all strains presented the same PCB biodegradation percentage, just 
four strains were further investigated (biodegradation level of more than $70 \%$ ). Out of the four strains, only Penicillium canescens contributed significantly to PCB biodegradation; it had fewer toxic metabolites, unlike P. chrysogenum which, in the biodegradation process, generated metabolites that proved to be much more toxic than PCBs $[143,144]$.

A dangerous material presented in wastewater that has a huge impact on human health (breast cancer, metabolic disorder in babies, prostate glands, etc.) is Bisphenol A (BPA) because of its property of endocrine disruption [145]. The removal of BPA by laccase, both in the presence and absence of rhamnolipid (RL) biosurfactant, was the main purpose for the research in paper [146]. The results proved that lower concentrations of RL registered a positive effect, unlike higher concentrations, which proved to be harmful.

\section{Degradation of Pharmaceutical Products}

With regard to decreasing damage to ecosystems due to global pollution, biotechnologists from all over the world are investigating and developing new non-polluting methods [2]. Thus, different treatments have been developed, such as physical, chemical, and biotechnological methods.

Pharmaceutical products represent the chemical substances (synthetic or natural) used in the prevention and treatment of diseases, or for the correction of human and animal organic functions. They include more than 4000 different molecules and have a large consumption of several thousand tons per year [147].

Pharmaceutical active compounds (PhACs) are included in the emerging pollutants category, because they are an important cause of pollution of the environment (soil and water); in addition, some PhACs are detected in drinking water and food, which directly threatens population health [148-150]. These organic micro-contaminants can be found in the aquatic environments of hospitals, and in industrial and domestic wastewaters (Figure 13) [147].

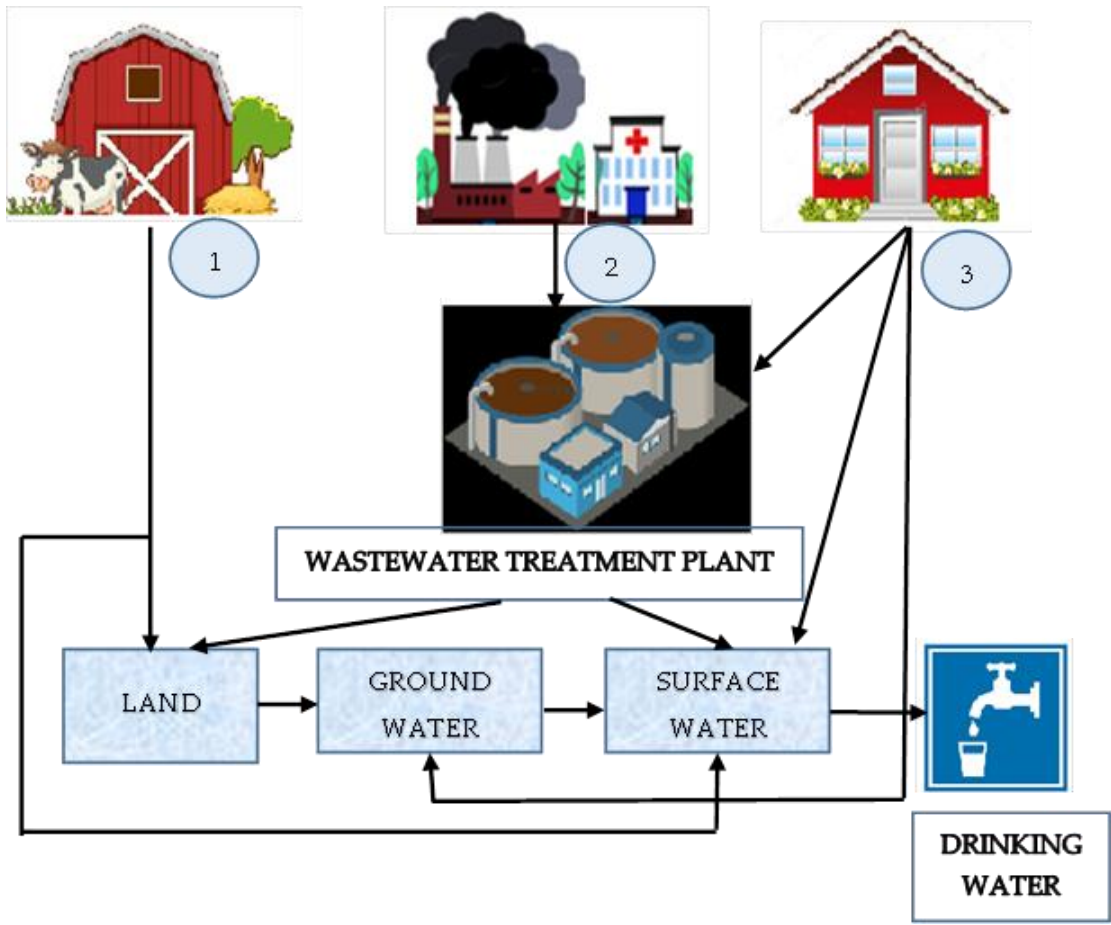

Figure 13. Potential sources of pharmaceutical pollution (modified from [147]): (1) animal husbandry; (2) industry and hospital; (3) household.

Considering the activity of pharmaceutical compounds, the literature presents the classification of pharmaceutical products, as can be seen in Figure 14. Important studies conducted in different countries across the world revealed that the following substances 
were found in surface- and ground-water bodies: analgesics, tranquilizers, antibiotics, steroids, lipid-lowering drugs, anti-inflammatories, antidepressants, beta-blockers, and stimulants [147].

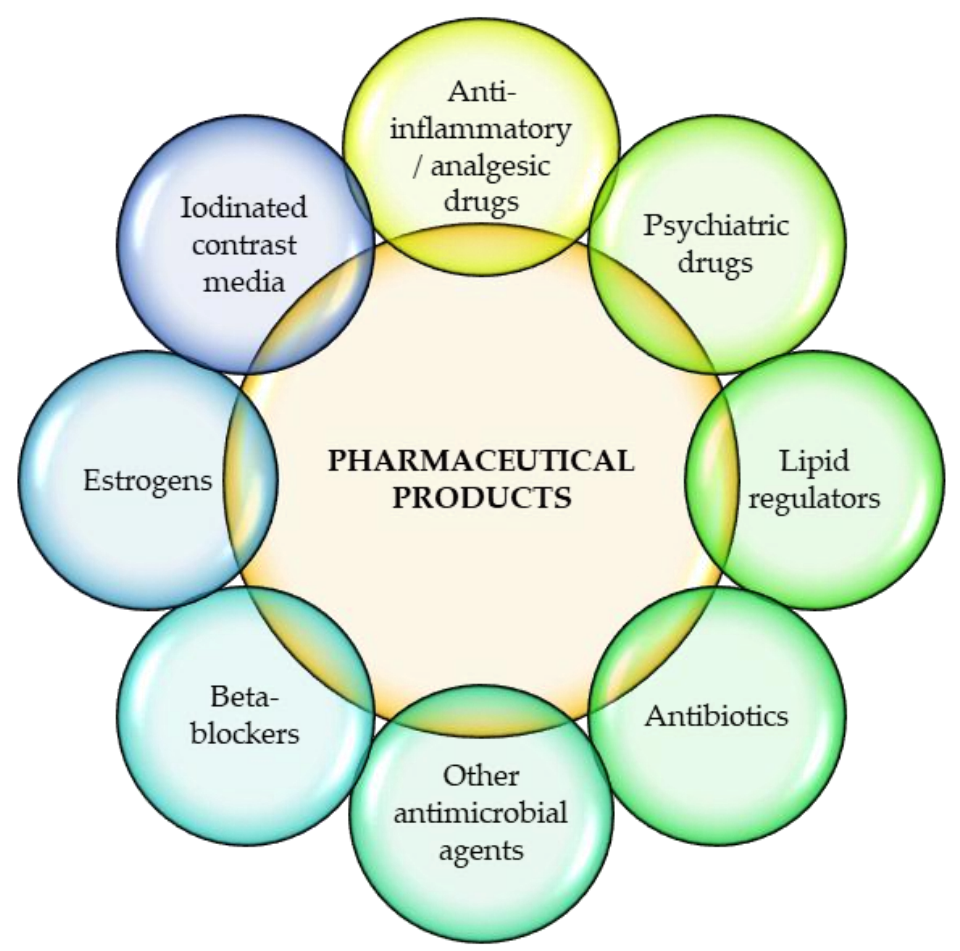

Figure 14. Pharmaceutical products categories (authors creation).

PhACs are often found in the surface water because the wastewater treatment plants cannot remove the low concentrations of contaminants or pharmaceutical active compounds [151,152]. Another reason of the micropollutants' presence in surface water is related to the fact that PhACs contain substances that are difficult to degrade [153]. Different studies available in the literature showed that conventional wastewater treatment plants are not efficient in pharmaceutical active compound removal [154-156]. Therefore, it is necessary to apply alternative innovative methods for water treatment that will be able to resolve the problem of PhAC removal, while being entirely environmentally friendly. In recent years, one of the most intensive research areas has been represented by the laccasemediated process for the decontamination of polluted water $[157,158]$. There are two methods of using enzymes: in free or immobilized forms. The immobilized laccase form presents some important advantages such as the preservation of enzymatic activity in time, or resistance to various process parameters (high temperature, interaction with chemical agents) [159]. Enzyme immobilization represents the process that locates (by adsorption, ionic forces, or covalent bonds) the enzyme on a support, which can be made from organic material, inorganic material or hybrid/composite materials, obtaining insoluble structures with enzymatic activity.

The group of white-rot fungi (WRF) are the most representative organisms that can degrade recalcitrant wood components (lignin, cellulose, and hemicellulose). This is possible as a result of extracellular non-specific enzymatic complexes (including the laccases) which are secreted predominantly in extracellular form. Considering this, many researchers have studied the WRF and have proved their capacity to degrade numerous organic compounds, including emerging contaminants such as pesticides, industrial chemicals, dyes, and pharmaceuticals [160-163].

The degradation of antibiotics was studied by Suda T. et al., in 2012 [164]. In their experiments, tetracycline (TC), chlortetracycline (CTC), doxycycline (DC), and oxytetracycline (OTC) were subjected to degradation process using laccase synthesized by Trametes 
versicolor, adding the redox mediator 1-hydroxybenzotriazole (HBT). The results demonstrated a complete elimination for tetracycline and chlortetracycline in $15 \mathrm{~min}$, but for doxycycline and oxytetracycline, $1 \mathrm{~h}$ was necessary for complete elimination.

In 2020, Zhang C. et al. [4] analyzed the degradation process for antibiotics using synthesized Laccase@Cu-BTC. A simple in-situ bio mineralization method was used in order to immobilize into a cooper-containing substrate (Trimesic acid framework, $\mathrm{Cu}-\mathrm{BTC}$ ) the laccase derived from Bacillus subtilis. The results showed the ability of Laccase@Cu-BTC to degrade tetracycline and ampicillin without any mediators. Compared to free laccase, the Laccase@Cu-BTC was proven to have a faster degradation rate than free laccase, which was consistent with the results measured by using ABTS as a substrate. The study also showed that the toxicity of products resulting from Laccase@Cu-BTC degradation were very weak compared with untreated antibiotics (tetracycline or ampicillin). For this purpose, the products resulting from the degradation process were incubated with two bacteria species (E. coli and Bacillus subtilis). In conclusion, the authors recommended the Laccase@Cu-BTC as an eco-friendly method for the degradation of antibiotics.

Yang J. et al. [165] also studied the degradation of antibiotics using a new form of magnetic cross-linked aggregate M-CLEA containing Cerrena laccase. The conclusion of the study was that Cerrena laccase M-CLEAs had the greatest results for tetracycline and oxytetracycline removal, followed by the degradation of ampicillin, sulfamethoxazole, and erythromycin. Additionally, the study concluded that $80 \%$ of tetracycline degradation happened in the first $12 \mathrm{~h}$, with the best degradation results obtained in $48 \mathrm{~h}$ for the following process condition: $25^{\circ} \mathrm{C}$ and $\mathrm{pH} 6$.

In 2019, Shao B. et al. [166] researched immobilized laccase efficiency for antibiotic contaminant removal. For the experiments, immobilized laccase was obtained using synthesized and modified hollow mesoporous carbon spheres (HMCs). Then, the immobilized laccase was utilized in the degradation of the antibiotics tetracycline hydrochloride (TCH) and ciprofloxacin hydrochloride (CPH). Good results for removal efficiency were obtained for both antibiotics (TCH and $\mathrm{CPH}$ ) when using redox mediators. Thus, the immobilized laccase in HMCs represents a method that can be used for reducing environmental pollution with antibiotics.

Experiments using commercial laccase from T. versicolor were conducted by Schwarz J. et al. [167] in order to demonstrate the degradation of three sulfonamides: sulfanilamide (SAA), sulfadimethoxine (SDT) and sulfapyridine (SPY). After 15 days, the following transformation percentages were registered: $10 \%$ for SAA, $75 \%$ for SDT, and $96 \%$ for SPY; these different values were attributed to the different molecular substituents.

The degradation of antibiotics by laccases was also studied by Guardado A.L.P. et al., in 2018 [150]. The paper presents a comparative study of three laccases' (Myceliophthora thermophila, T. versicolor and Pycnoporus sanguineus CS43) degradation efficiencies on antibiotics (amoxicillin, ciprofloxacin, and sulfamethoxazole). Without using any redox mediators, the degradation process of antibiotics was not successful, except for the amoxicillin, which was degraded in all cases. Other experiments were conducted using three redox mediatorsnamely syringaldehyde, p-coumaric acid, and ABTS - for studying their influence on the degradation process by laccases. The results showed that the best redox mediator was syringaldehyde, which reached the best degradation percentages after $3 \mathrm{~h}$ of treatment: $80 \%$ for amoxicillin, $100 \%$ for sulfamethoxazole, and $40 \%$ for ciprofloxacin. Additionally, the study concluded that the commercial laccases produced by $M$. thermophila and T. versicolor presented better catalytic performance compared with novel laccase produced by $P$. sanguineus CS43.

The degradation of chloramphenicol using laccase from Trametes hirsuta and various mediators was investigated by Navada K.K. et al. [168], in 2019. In seven days, the laccase enzyme, without mediators, achieved the removal of $0.5 \mathrm{mg} / \mathrm{L}$ chloramphenicol. The study also proved that for an efficient degradation of higher concentrations of chloramphenicol $(10 \mathrm{mg} / \mathrm{L})$, it is necessary to use a laccase mediator system (LMS), such as syringaldehyde, 
vanillin, ABTS, or $\alpha$-naphthol. In the case of using mediators, the degradation rate is enhanced from $10 \%$ to $100 \%$ during $48 \mathrm{~h}$.

Jureczko M. et al. [169] investigated the removal efficiency of anticancer drugs (bleomycin and vincristine) by the laccases obtained from five white-rot fungus species: Fomes fomentarius (CB13), Hypholoma fasciculare (CB15), Phyllotopsis nidulans (CB14), Pleurotus ostreatus (BWPH), and Trametes versicolor (CB8). The experiments revealed a vincristine degradation rate $>94 \%$ by CB13, CB15 and CB8 after 4 days; however, in the case of bleomycin, after 9 days, the degradation rate was only $36 \%$ by CB8, and $25 \%$ by CB15. The degradation of bleomycin and vincristine was in accordance with the laccase production.

Another study regarding the removal of anticancer drugs using laccase was made by Kelbert M. et al., in 2021 [170]. The researchers evaluated the efficiency of laccase from Trametes versicolor on doxorubicin degradation for various operating conditions, meaning enzyme concentrations, $\mathrm{pH}$, and temperature. The experiments showed that laccase degrades doxorubicin for all concentrations all these drugs $(50,250$ and $500 \mu \mathrm{g} / \mathrm{mL}$ ). It was demonstrated that the required degradation time is inversely proportional to the laccase amount. Another conclusion of the study was that when the laccase concentration increased from 900 to $1800 \mathrm{U} / \mathrm{L}$, the specific initial degradation rate decreased; this means that a great number of enzymes is not necessary for the degradation process. The best degradation result was obtained at a temperature of $30^{\circ} \mathrm{C}$ and $\mathrm{pH} 7$, which is similar to wastewater treatment plant conditions.

The biodegradation of diclofenac using crude laccase from Trametes trogii was studied by Aracagök Y.D. et al. [171], in 2018. The study showed a 97\% degradation rate of diclofenac, in $48 \mathrm{~h}$, by crude laccase from $\mathrm{T}$. trogii. The researchers also indicated that the biodegradation process was influenced by the $\mathrm{pH}$ and temperature. Thus, the maximum diclofenac percentage removal (95\% and $97 \%$ ) was obtained at $\mathrm{pH}$ values of 4.5 and 5 . While varying the temperature between $15-55^{\circ} \mathrm{C}$ at $\mathrm{pH} 5$, a maximum diclofenac removal was found $(99 \%)$ at $30^{\circ} \mathrm{C}$.

Yusnidar Y. [172], in 2020, realized a study on the biodegradation of diclofenac and ibuprofen from pharmaceutical industry waste using a laccase enzyme immobilized with graphene oxide (GO). It was observed that the GO-laccase system can be successfully used on the removal process of the pharmaceutical products studied in the experiments.

The degradation process of naproxen and diclofenac, two wide-spread anti-inflammatories, using laccase enzyme was studied by Zdarta J. et al. [173] in 2019. For the study, the support for laccase immobilization was poly(l-lactic acid)-co-poly( $\varepsilon$-caprolactone) (PLCL) electrospun nanofibers. The results showed that, in batch mode, a removal rate of higher than $90 \%$ was obtained for both anti-inflammatory compounds by encapsulated laccase, at a temperature of $25^{\circ} \mathrm{C}$, and when $\mathrm{pH}$ was 5 for naproxen, and 3 for diclofenac. Additionally, the experiments proved a high reuse rate of the immobilized laccases; after five treatment cycles, removal rates of about $60 \%$ and $40 \%$ for naproxen and diclofenac were obtained.

In a paper from 2021, Masjoudi M. et al. [174] showed the influence of the covalently immobilized laccase from Trametes hirsuta on the removal of two pharmaceutical compounds. For their experiments, the authors used an immobilized laccase in a minimembrane reactor for the removal of carbamazepine and diclofenac. The experiments proved a removal efficiency of $27 \%$ in $48 \mathrm{~h}$ for the carbamazepine, while for diclofenac, the removal efficiency was $95 \%$ in $4 \mathrm{~h} \mathrm{[175].}$

Another study regarding diclofenac (DFC) degradation was made by Primožič M. et al. in 2020 [176]. The results of the experiments revealed a high degradation rate of diclofenac by CLEAs laccase (cross-linked enzyme aggregates) and mCLEA laccase (magnetic cross-linked enzyme aggregates) compared to unlinked laccase. The removal capacity in optimum process conditions had the following values: for unlinked laccase, $11.5 \pm 0.3 \mu \mathrm{g}$ DCF/g laccase; for CLEAs, $15.6 \pm 0.4 \mu \mathrm{g}$ DCF/g laccase; and for mCLEAs, $13.6 \pm 0.4 \mu \mathrm{g}$ DCF/g laccase. The authors concluded that the CLEA laccase and mCLEA laccase is a recommended solution for diclofenac removal from polluted wastewaters. 
Likewise, a study realized by Lloret L. et al. in 2010 [177] reported a complete degradation of diclofenac by purified laccase from Myceliophthora thermophile using mediators; in addition, for the experiments realized without mediators, the degradation of diclofenac was at $83 \%$.

Tran N.H. et al. [178] investigated the removal process of some anti-inflammatory drugs (fenoprofen, indomethacin and propyphenazone) using laccase from T. versicolor. The results showed a removal rate $>90 \%$ after $3 \mathrm{~h}$ for fenoprofen and the same removal rate after $30 \mathrm{~min}$ for indomethacin, while for propyphenazone, the removal rate was $25 \%$ after $3 \mathrm{~h}$.

Jahangiri E. et al. [179] demonstrated the efficiency of laccase from Phoma sp. UHH 5-1-03, cross-linked to polyvinylidene fluoride membranes, on the removal process of indomethacin, mefenamic acid, acetaminophen, bezafibrate, ketoprofen, and naproxen. A high efficiency of the process was obtained after the experiments.

Kang B.R. et al. [180], in 2021, conducted a study regarding the degradation process of pharmaceuticals by native fungal enzymes. For the experiments, the researchers used enzymes from Bjerkandera spp. TBB-03 for the removal of two pharmaceutical products, acetaminophen $(\mathrm{ACN})$ and carbamazepine (CMZ), under various conditions. After $24 \mathrm{~h}$ of treatment with laccase, at different temperatures, the remaining concentrations of ACN and $\mathrm{CMZ}$ were determined. It was concluded that the heat-inactivated control did not have big influence on $\mathrm{ACN}(<4 \%)$, while the CMZ presented an important decrease $(20.5 \pm 2.4 \%)$. The complete degradation of the ACN was obtained after $2 \mathrm{~h}$ at temperatures of $25{ }^{\circ} \mathrm{C}$, $30{ }^{\circ} \mathrm{C}$, and $40{ }^{\circ} \mathrm{C}$, while for temperature of $15^{\circ} \mathrm{C}$ and $5^{\circ} \mathrm{C}, 6$ and $12 \mathrm{~h}$, respectively, were necessary. Considering the variation of the $\mathrm{pH}$, it was observed that the ACN was fully degraded after $2 \mathrm{~h}$ at 5-7 $\mathrm{pH}$ values. On the other hand, during the experiments, CMZ could not be degraded for any $\mathrm{pH}$ values. Another conclusion of the study was that the pharmaceuticals were not removed at $\mathrm{pH} 8$.

The degradation of diclofenac, trimethoprim, carbamazepine, and sulfamethoxazole during treatment with laccase from Trametes versicolor was studied by Alharbi S.K. et al. in 2019 [181]. The experiments were realized in two ways: the pharmaceuticals were used individually, or a mixture was made with various concentrations $(1.25$ and $5 \mathrm{mg} / \mathrm{L}$ for every compound). The removal efficiency of the four compounds was higher when tested individually than when tested in mixtures. Another conclusion was that a lower initial concentration will conduce to a lower efficiency for the degradation of trimethoprim, carbamazepine, and sulfamethoxazole in mixture, compared to the results obtained for higher initial concentrations, in both the individual and mixture methods.

Enzymatic degradation with laccase of some pharmaceutical compounds was investigated by Taheran M. et al. [182], in 2017. For the experiments, the laccases were immobilized on a polyacrylonitrile-biochar composite nanofibrous membrane. Further, the resulted laccase system was used for the degradation, in batch mode, of chlortetracycline, carbamazepine, and diclofenac, which represent the most important categories of pharmaceuticals: antibiotics, antidepressants, and anti-inflammatories. After the experiments, the following degradation rates were obtained using immobilized laccase: $72.7 \%$ for DCF, $63.3 \%$ for CTC, and $48.6 \%$ for CBZ.

In 2018, Naghdi M. et al. [183] conducted research regarding the biodegradation of carbamazepine, which represents one of the most widely used pharmaceutical compounds around the world. Crude laccase was obtained from Trametes versicolor and employed for the CBZ removal, in both cases of using, or not using, the ABTS mediator. The study investigated the influence of process parameters and their interactions on the degradation of CBZ. The results demonstrated the influence of ABTS concentration, $\mathrm{pH}$, temperature, and enzyme concentration on the removal efficiency of carbamazepine. The best result of the experiments-meaning a 95\% removal efficiency of CBZ after $24 \mathrm{~h}$-was obtained in the following conditions: $35^{\circ} \mathrm{C}$ temperature, $\mathrm{pH} 6,60 \mathrm{U} / \mathrm{L}$ of laccase concentration and $18 \mu \mathrm{M}$ of ABTS concentration. In conclusion, the authors recommended the use of a laccase-ABTS system in the degradation of carbamazepine from polluted wastewaters. The degradation 
of antimicrobial and preservative agent triclosan (TCS) using laccase from T. versicolor was studied by Inoue et al., in 2010 [184]. The study showed that laccase removed about $51 \%$ of TCS from the reaction mixture after $90 \mathrm{~min}$. Additionally, the use of a laccase-HBT system enhanced the elimination of TCS at $66 \%$.

The results obtained from the studies show that the capacity of the laccase enzyme to catalyze the removal of pharmaceuticals is influenced by various factors, such as substrate type, reaction parameters and enzyme properties. Additionally, the source of the enzymes is a factor that affect the process performance, meaning that the biodegradation of the same pharmaceutical using enzymes obtained from various sources leads to different degradation rates.

In order to overcome the limitations presented by laccases, two new methods were developed: the laccase mediator system and laccase immobilization. The ability of redox mediators to improve the removal process of pharmaceuticals depends on the structure of the compounds and, in some singular situations, it can conduce to a higher toxicity of the involved aqueous media $[185,186]$. Thus, for good results in the degradation process, it is required to select the appropriate mediator and its optimal concentration [150]. Enzyme immobilization is a method that presents the advantage of a continuous operation, enhances enzyme stability, and facilitates the reuse of laccases.

\section{Conclusions}

As can be observed from all the data presented, laccases can be used in the treatment of the agro-waste and food industries; the degradation of pesticides, drug, and cosmetic residues; the decolorization of dyes; the degradation of residues of the pulp and paper industry, etc. The variety of sources of laccases (plant, bacterial, and fungal laccases) highlights their versatility and involvement in different types of processes. Their properties make them ideal for the biodegradation of environmental pollutants. Additionally, a very important element that should be mentioned is related to immobilization techniques that are studied in close connection with zero-waste principles.

Regarding agro-waste treatment by laccases, the main idea that needs to be highlighted is that laccase enzymes have an essential contribution in lignin decomposition. The advantages, in this case, are closely connected to the association of physical, chemical, and physical-chemical pretreatment methods with biological treatment applied to LB, which can help the industry to better apply the treatments and the processes for biodegradation.

If we look forward to the degradation of xenobiotic compounds, we can conclude that there are some disadvantages that need to be mentioned, such as high costs, poor reusability, a loss of enzyme activity, and low yields; however, laccase enzymes are still highly important in different types of industries. Additionally, fungal laccases act on xenobiotic substances such as phenolic compounds, aromatic amines, PAHs, drugs, synthetic dyes, and other substrates, which they turn into less toxic compounds.

Another area in which laccases showed potential is related to dye decolorization, mainly due to the fact that synthetic paints are seen as a very important pollutant with an impact on the environment. Laccases are well-known for their ability to degrade synthetic dyes in wastewater and soil, producing fewer toxic compounds; this is demonstrated through the research presented. Although there are many, further studies are required to help in improving not just the environmental aspects, but also to improve human health security.

The pharmaceutics sector is a very important part of human life, and the increased consumption of medicine requires better techniques and technologies to degrade the pharmaceutical compounds that can be found in water and soil. The studies revealed that the use of laccases is an effective method for degrading pharmaceutical products.

Laccases are versatile green enzymes with significant potential in the degradation of harmful and toxic pollutants. Due to their low specificity for substrate, laccases can adapt to a high variety of compounds that come from industry and agriculture, and continue to expand their diversification according to the evolution of human impact on 
the environment. One of the challenges that needs to be considered is the optimization of the process of biosynthesis and the action of these enzymes from a small laboratory scale to industrial applications. Additionally, the opportunities in this case seem to apply to reaching a sustainable environment in the context of a circular economy, in line with the desire of 2030 European Strategy.

Nowadays laccases represent a research topic for the degradation of xenobiotic compounds, dyes and pharmaceutical products. The cost problems related to laccase usage require studies regarding the improvement of their stability, through the discovery of new sources, action parameter optimization, enzyme stabilization and immobilization using new biodegradable compounds. The microbial biosynthesis of enzymes is an expensive process, but costs can be reduced by (1) the use of cheap culture media containing agri-food by-products; (2) the use of mutant strains with high productive potential; (3) cultivating fungi under solid state fermentation, which is cheaper than submerged cultures; (4) coupling obtaining edible fungal biomass (from some Basidiomycetes) with the synthesis of laccases, which are found in the liquid part of the culture; as well as other solutions. Considering the large amount of substrate or wastewater to be treated, the costs could be reduced by treating the pollutants directly at the source, where the amount of enzyme is minimal.

Nonetheless, continuous investigation of the techniques, technologies, processes, parameters, compounds, etc. needs to evolve to find those efficient and feasible methods that can be applied to each industry and to ensure environmental sustainability. Due to the technological evolution in the last 30 years, laccase enzymes have been intensively studied and applied as being green and environmentally friendly alternatives for pollutant degradation.

Author Contributions: Conceptualization, G.P. and M.F.; methodology, M.F.; validation, G.P. and M.F.; formal analysis, B.S.Z. and M.I.; investigation, M.N.D. and G.M.; writing-original draft preparation, B.S.Z., M.I., M.N.D. and G.M.; writing—review and editing, M.F.; visualization, M.N.D. and G.M.; supervision, G.P. All authors have read and agreed to the published version of the manuscript.

Funding: This research was supported by the University POLITEHNICA of Bucharest.

Institutional Review Board Statement: Not applicable.

Informed Consent Statement: Not applicable.

Data Availability Statement: Not applicable.

Conflicts of Interest: The authors declare no conflict of interest.

\section{References}

1. Dana, M.; Khaniki, G.B.; Mokhtarieh, A.A.; Davarpanah, S.J. Biotechnological and Industrial Applications of Laccase: A Review. J. Appl. Biotechnol. Rep. 2017, 4, 675-679.

2. Arregui, L.; Ayala, M.; Gomez Gil, X.; Gutierrez Soto, G.; Hernandez Luna, C.E.; de los Santos, M.H.; Levin, L.; Rojo Dominguez, A.; Romero Martinez, D.; Saparrat, M.C.N.; et al. Laccases: Structure, function, and potential application in water bioremediation. Microb. Cell. Fact. 2019, 18, 200. [CrossRef] [PubMed]

3. Debnath, R.; Saha, T. An insight into the production strategies and applications of the ligninolytic enzyme laccase from bacteria and fungi. Biocatal. Agric. Biotechnol. 2020, 26, 101645. [CrossRef]

4. Zhang, C.; You, S.; Zhang, J.; Qi, W.; Su, R.; He, Z. An effective in-situ method for laccase immobilization: Excellent activity, effective antibiotic removal rate and low potential ecological risk for degradation products. Bioresour. Technol. 2020, $308,123271$. [CrossRef] [PubMed]

5. Iark, D.; dos Reis Buzzo, A.J.; Garcia, J.A.A.; Correa, V.G.; Helm, C.V.; Correa, R.C.G.; Peralta, R.A.; Regina de Fatima, P.; Bracht, A.; Peralta, R.M. Enzymatic degradation, and detoxification of azo dye Congo red by a new laccase from Oudemansiella canarii. Bioresour. Technol. 2019, 289, 121655. [CrossRef]

6. Singh, G.; Arya, S.K. Utility of laccase in pulp and paper industry: A progressive step towards the green technology. Int. J. Biol. Macromol. 2019, 134, 1070-1084. [CrossRef]

7. Janusz, G.; Pawlik, A.; Swiderska-Burek, U.; Polak, J.; Sulej, J.; Jarosz-Wilkołazka, A.; Paszczynski, A. Laccase Properties, Physiological Functions, and Evolution. Int. J. Mol. Sci. 2020, 21, 966. [CrossRef] 
8. Christopher, L.P.; Yao, B.; Ji, Y. Lignin biodegradation with laccase-mediator systems. Front. Energy Res. 2014, 2, 12. [CrossRef]

9. Góralczyk-Bińkowska, A.; Jasińska, A.; Długoński, J. Characteristics and use of multicopper oxidases enzymes. Post. Mikrobiol. 2019, 58, 7-18. [CrossRef]

10. Sondhi, S.; Kaur, R.; Madan, J. Purification and characterization of a novel white highly thermo stable laccase from a novel Bacillus sp. MSK-01 having potential to be used as anticancer agent. Int. J. Biol. Macromol. 2021, 170, 232-238. [CrossRef]

11. Polak, J. Structure/Redox potential relationship of simple organic compounds as potential precursors of dyes for laccase-mediated transformation. Biotechnol. Progr. 2012, 28, 93-102. [CrossRef] [PubMed]

12. Wang, H.; Deng, W.; Shen, M.; Yan, G.; Zhao, W.; Yang, Y. A laccase Gl-LAC-4 purified from white-rot fungus Ganoderma lucidum had a strong ability to degrade and detoxify the alkylphenol pollutants 4-n-octylphenol and 2-phenylphenol. J. Hazard. Mater. 2021, 408, 124775. [CrossRef] [PubMed]

13. Wong, D.S. Structure and action mechanism of ligninolytic enzymes. Appl. Microbiol. Biotechnol. 2009, 157, 174-209. [CrossRef] [PubMed]

14. Shekher, S.R.; Sehgal, S.; Sehgal, S.; Kamthania, M.; Kumar, A. Laccase: Microbial Sources, Production, Purification, and Potential Biotechnological Applications. Enzyme Res. 2011, 2011, 217861. [CrossRef]

15. Agrawal, K.; Chaturvedi, V.; Verma, P. Fungal laccase discovered but yet undiscovered. Bioresour. Bioprocess. 2018, 5, 4. [CrossRef]

16. Riva, S. Laccases: Blue enzymes for green chemistry. Trends Biotechnol. 2006, 24, 219-226. [CrossRef]

17. Barrios-Estrada, C.; Rostro-Alanis, M.; Parra, A.L.; Belleville, M.P.; Sanchez-Marcano, J.; Iqbal, H.M.N.; Parra-Saldívar, R. Potentialities of active membranes with immobilized laccase for Bisphenol A degradation. Int. J. Biol. Macromol. 2018, 108, 837-844. [CrossRef]

18. Strong, P.J.; Claus, H. Laccase: A review of its past and its future in bioremediation. Crit. Rev. Environ. Sci. Technol. 2011, 41, 373-434. [CrossRef]

19. Piontek, K.; Antorini, M.; Choinowski, T. Crystal structure of a laccase from the fungus Trametes versicolor at 1.90-Å resolution containing a full complement of coppers. J. Biol. Chem. 2007, 277, 37663-37669. [CrossRef]

20. Das, R.; Liang, Z.; Li, G.; An, T. A non-blue laccase of Bacillus sp. GZB displays manganese-oxidase activity: A study of laccase characterization, $\mathrm{Mn}$ (II) oxidation and prediction of Mn(II) oxidation mechanism. Chemosphere 2020, 252, 126619. [CrossRef]

21. Gochev, V.K.; Krastanov, A.I. Fungal Laccases. Bulg. J. Agric. Sci. 2007, 13, 75-83.

22. Bassanini, I.; Ferrandi, E.E.; Riva, S.; Monti, D. Biocatalysis with Laccases: An Updated Overview. Catalysts 2021, 11, 26. [CrossRef]

23. Díaz, R.; Alonso, S.; Díaz, R.; Alonso, S.; Sánchez, C.; Tomasini, A.; Bibbins-Martínez, M.; Díaz-Godínez, G. Characterization of the growth and laccase activity of strains of Pleurotus ostreatus in submerged fermentation. BioResources 2011, 6, 282-290. [CrossRef]

24. Zofair, S.F.F.; Arsalan, A.; Khan, M.A.; Alhumaydhi, F.A.; Younus, H. Immobilization of laccase on Sepharose-linked antibody support for decolourization of phenol red. Int. J. Biol. Macromol. 2020, 161, 78-87. [CrossRef]

25. Daronch, N.A.; Kelbert, M.; Pereira, C.S.; de Araujo, P.H.H.; de Oliveira, D. Elucidating the choice for a precise matrix for laccase immobilization: A Review. Chem. Eng. J. 2020, 397, 125506. [CrossRef]

26. Aslam, S.; Asgher, M.; Khan, N.A.; Bilal, M. Immobilization of Pleurotus nebrodensis WC 850 laccase on glutaraldehyde cross-linked chitosan beads for enhanced biocatalytic degradation of textile dyes. J. Water Process Eng. 2021, 40, 101971. [CrossRef]

27. Alvarado-Ramírez, L.; Rostro-Alanis, M.; Rodríguez-Rodríguez, J.; Castillo-Zacarías, C.; Sosa-Hernández, J.E.; Barceló, D.; Iqbal, H.M.N.; Parra-Saldívar, R. Exploring current tendencies in techniques and materials for immobilization of laccases-A review. Int. J. Biol. Macromol. 2021, 181, 683-696. [CrossRef]

28. Qian, E.W. Pretreatment and saccharification of lignocellulosic biomass. In Research Approaches to Sustainable Biomass Systems; Tojo, S., Hirasawa, T., Eds.; Academic Press: Cambridge, MA, USA, 2014; Chapter 7; pp. 181-204. [CrossRef]

29. Wang, F.; Ouyang, D.; Zhou, Z.; Page, S.J.; Liu, D.; Zhao, X. Lignocellulosic biomass as sustainable feedstock and materials for power generation and energy storage. J. Energy Chem. 2021, 57, 247-280. [CrossRef]

30. Xu, F.; Li, Y. Biomass digestion. In Encyclopedia of Sustainable Technologies; Abraham, M.A., Ed.; Elsevier: Amsterdam, The Netherlands, 2017; pp. 197-204. [CrossRef]

31. Zheng, Y.; Shi, J.; Tu, M.; Cheng, Y.S. Principles and development of lignocellulosic biomass pretreatment for biofuels. In Advances in Bioenergy; Li, Y., Ge, X., Eds.; Elsevier: Amsterdam, The Netherlands, 2017; Chapter One; Volume 2, pp. 1-68. [CrossRef]

32. Hernandez-Beltran, J.U.; Hernandez-De Lira, I.O.; Cruz-Santos, M.M.; Saucedo-Luevanos, A.; Hernandez-Teran, F.; Balagurusamy, N. Insight into pretreatment methods of lignocellulosic biomass to increase biogas yield: Current state, challenges and opportunities. Appl. Sci. 2019, 9, 3721. [CrossRef]

33. Kumar, A.K.; Sharma, S. Recent updates on different methods of pretreatment of lignocellulosic feedstocks: A review. Bioresour. Bioprocess 2017, 4, 7. [CrossRef]

34. Baruah, J.; Nath, B.K.; Sharma, R.; Kumar, S.; Deka, R.C.; Baruah, D.C.; Kalita, E. Recent trends in the pretreatment of lignocellulosic biomass for value-added products. Front. Energy Res. 2018, 6, 141. [CrossRef]

35. Taherzadeh, M.J.; Karimi, K. Pretreatment of lignocellulosic wastes to improve ethanol and biogas production: A Review. Int. J. Mol. Sci. 2008, 9, 1621-1651. [CrossRef] [PubMed]

36. Preethi Gunasekaran, M.; Gopalakrishnan, K.; Obulisamy Parthiba, K.; Sunita, V.; Rajesh Banu, J. Lignocellulosic biomass as an optimistic feedstock for the production of biofuels as valuable energy source: Techno-economic analysis, Environmental Impact Analysis, Breakthrough and Perspectives. Environ. Technol. Innov. 2021, 24, 102080. [CrossRef] 
37. Karuppiah, T.; Azariah, V.E. Biomass pretreatment for enhancement of biogas production. In Anaerobic Digestion; Rajesh Banu, J., Ed.; IntechOpen: London, UK, 2019; Chapter 5. [CrossRef]

38. Amin, F.R.; Khalid, H.; Zhang, H.; Rahman, S.U.; Zhang, R.; Liu, G.; Chen, C. Pretreatment methods of lignocellulosic biomass for anaerobic digestion. AMB Express 2017, 7, 72. [CrossRef] [PubMed]

39. Mankar, A.; Pandey, A.; Modak, A.; Pant, K.K. Pretreatment of lignocellulosic biomass: A review on recent advances. Bioresour. Technol. 2021, 334, 125235. [CrossRef]

40. Otto Wagner, A.; Lackner, N.; Mutschlechner, M.; Prem, E.M.; Markt, R.; Illmer, P. Biological pretreatment strategies for second-generation lignocellulosic resources to enhance biogas production. Energies 2018, 11, 1797. [CrossRef]

41. Najiah, N.; Nur Liyana, I.; Azlan Shah, H. Fungal pretreatment of lignocellulosic materials. In Biomass for Bioenergy-Recent Trends and Future Challenges; Abd El-Fatah, A., Ed.; IntechOpen: London, UK, 2019; Chapter 3. [CrossRef]

42. Mishra, S.; Singh, P.K.; Dash, S.; Pattnaik, R. Microbial pretreatment of lignocellulosic biomass for enhanced biomethanation and waste management. 3 Biotech 2018, 8, 458. [CrossRef]

43. Abraham, A.; Mathew, A.K.; Park, H.; Choi, O.; Sindhu, R.; Parameswaran, B.; Pandey, A.; Park, J.H.; Sang, B.I. Pretreatment strategies for enhanced biogas production from lignocellulosic biomass. Bioresour. Technol. 2020, 301, 122725. [CrossRef]

44. Fillat, U.; Ibarra, D.; Eugenio, M.E.; Moreno, A.D.; Tomas-Pejo, E.; Martin-Sampedro, R. Laccases as a potential tool for the efficient conversion of lignocellulosic biomass: A review. Fermentation 2017, 3, 17. [CrossRef]

45. Jin, X.; Ai, W.; Dong, W. Lignocellulose degradation, biogas production and characteristics of the microbial community in solid-state anaerobic digestion of wheat straw waste. Life Sci. Space Res. 2022, 32, 1-7. [CrossRef]

46. Schroyen, M.; Vervaeren, H.; Van Hulle, S.W.H.; Raes, K. Impact of enzymatic pretreatment on corn stover degradation and biogas production. Bioresour. Technol. 2014, 173, 59-66. [CrossRef] [PubMed]

47. Schroyen, M.; Van Hulle, S.W.H.; Holemans, S.; Vervaeren, H.; Raes, K. Laccase enzyme detoxifies hydrolysates and improves biogas production from hemp straw and miscanthus. Bioresour. Technol. 2017, 244, 597-604. [CrossRef]

48. Wyman, V.; Henríquez, J.; Palma, C.; Carvajal, A. Lignocellulosic waste valorisation strategy through enzyme and biogas production. Bioresour. Technol. 2018, 247, 402-411. [CrossRef] [PubMed]

49. Yadav, M.; Vivekanand, V. Chaetomium globosporum: A novel laccase producing fungus for improving the hydrolyzability of lignocellulosic biomass. Heliyon 2019, 5, e01353. [CrossRef] [PubMed]

50. Yadav, M.; Singh, A.; Balan, V.; Pareek, N.; Vivekanand, V. Biological treatment of lignocellulosic biomass by Chaetomium globosporum: Process derivation and improved biogas production. Int. J. Biol. Macromol. 2019, 128, 176-183. [CrossRef]

51. Yadav, M.; Vivekanand, V. Biological treatment of lignocellulosic biomass by Curvularia lunata for biogas production. Bioresour. Technol. 2020, 306, 123151. [CrossRef]

52. Fithri, L.; Puspaningsih, N.N.T.; Asmarani, O.; Fitrah Dewi, N.G.D.; Arizandy, R.Y. Characterization of fungal laccase isolated from oil palm empty fruit bunches (OPEFB) and its degradation from the agriculture waste. Biocatal. Agric. Biotechnol. 2020, 27, 101676. [CrossRef]

53. Cai, Y.; Zheng, Z.; Schafer, F.; Stinner, W.; Yuan, X.; Wang, H.; Cui, Z.; Wang, X. A review about pretreatment of lignocellulosic biomass in anaerobic digestion: Achievement and challenge in Germany and China. J. Clean. Prod. 2021, 299, 126885. [CrossRef]

54. Bruni, E.; Jensen, A.P.; Angelidaki, I. Comparative study of mechanical, hydrothermal, chemical and enzymatic treatments of digested biofibers to improve biogas production. Bioresour. Technol. 2010, 101, 8713-8717. [CrossRef]

55. Sijinamanoj, V.; Muthukumar, T.; Muthuraja, R.; Rayappan, K.; Karmegam, N.; Saminathan, K.; Govarthanan, M.; Kathireswari, P. Ligninolytic valorization of agricultural residues by Aspergillus nomius and Trichoderma harzianum isolated from gut and comb of Odontotermes obusus (Termitidae). Chemosphere 2021, 284, 131384. [CrossRef]

56. Albornoz, S.; Wyman, V.; Palma, C.; Carvajal, A. Understanding of the contribution of the fungal treatment conditions in a wheat straw biorefinery that produces enzymes and biogas. Biochem. Eng. J. 2018, 140, 140-147. [CrossRef]

57. Mustafa, A.M.; Poulsen, T.G.; Sheng, K. Fungal pretreatment of rice straw with Pleurotus ostreatus and Trichoderma reesei to enhance methane production under solid-state anaerobic digestion. Appl. Energy 2016, 180, 661-671. [CrossRef]

58. Salvachua, D.; Prieto, A.; Lopez-Abelairas, M.; Lu-Chau, T.; Martinez, A.T.; Martinez, M.J. Fungal pretreatment: An alternative in second-generation ethanol from wheat straw. Bioresour. Technol. 2011, 102, 7500-7506. [CrossRef] [PubMed]

59. Chang, K.L.; Liu, C.H.; Phitsuwan, P.; Ratanakhanokchai, K.; Lin, Y.C.; Dong, C.D.; Lin, M.H.; Yang, G.C.C. Enhancement of biological pretreatment on rice straw by an ionic liquid or surfactant. Catalysts 2021, 11, 1274. [CrossRef]

60. Moreno, A.D.; Ibarra, D.; Mialon, A.; Ballesteros, M. A bacterial laccase for enhancing saccharification and ethanol fermentation of steam-pretreated biomass. Fermentation 2016, 2, 11. [CrossRef]

61. Liu, S.; Liu, H.; Shen, C.; Fang, W.; Xiao, Y.; Fang, Z. Comparison of performances of different fungal laccases in delignification and detoxification of alkali-pretreated corncob for bioethanol production. J. Ind. Microbiol. Biotechnol. 2021, 48, kuab013. [CrossRef]

62. Yu, H.; Du, W.; Zhang, J.; Ma, F.; Zhang, X.; Zhong, W. Fungal treatment of cornstalks enhances the delignification and xylan loss during mild alkaline pretreatment and enzymatic digestibility of glucan. Bioresour. Technol. 2010, 101, 6728-6734. [CrossRef]

63. Oliva-Taravilla, A.; Tomas-Pejo, E.; Demuez, M.; Gonzalez-Fernandez, C.; Ballesteros, M. Effect of laccase dosage on enzymatic hydrolysis of steam exploded wheat straw. Cellulose Chem. Technol. 2016, 50, 391-395.

64. Deng, Z.; Xia, A.; Liao, Q.; Zhu, X.; Huang, Y.; Fu, Q. Laccase pretreatment of wheat straw: Efects of the physicochemical characteristics and the kinetics of enzymatic hydrolysis. Biotechnol. Biofuels 2019, 12, 159. [CrossRef] 
65. Mustafa, A.M.; Poulsen, T.G.; Xia, Y.; Sheng, K. Combinations of Fungal and Milling Pretreatments for Enhancing Rice Straw Biogas Production during Solid-State Anaerobic Digestion. Bioresour. Technol. 2017, 224, 174-182. [CrossRef]

66. Saurabh, S.; Deepak, G.; Anushree, M. Decolourization of textile effluent using native microbial consortium enriched from textile industry effluent. J. Hazard. Mat. 2021, 402, 123835.

67. Legerská, B.; Chmelová, D.; Ondrejovič, M. Degradation of synthetic dyes by laccases-a mini-review. Nova Biotechnol. Chim. 2016, 15, 90-106. [CrossRef]

68. Sudha, M.; Saranya, A.; Selvakumar, G.; Sivakumar, N. Microbial degradation of azo dyes: A review. Int. J. Curr. Microbiol. 2014, 3, 670-690.

69. Patel, A.M.; Patel, V.M.; Pandya, J.; Trivedi, U.B.; Patel, K.C. Evaluation of catalytic efficiency of Coriolopsis caperata DN laccase to decolorize and detoxify RBBR dye. Water Conserv. Sci. Eng. 2017, 2, 85-98. [CrossRef]

70. Chung, K.T.; Cerniglia, C.E. Mutagenicity of azo dyes: Structure-activity relationships. Mutat. Res. 1992, 227, 201-220. [CrossRef]

71. Yanto, D.H.Y.; Auliana, N.; Watanabe, T. Decolorization of synthetic textile dyes by laccase from newly isolated Trametes hirsuta EDN084 mediated by violuric acid. IOP Conf. Ser. Earth Environ. Sci. 2019, 374, 012005. [CrossRef]

72. Theerthagiri, J.; Venugopal, M.; Arun, P.E.; Sivaraman, C.; Palaniyandy, N.; Ziyauddin, K.; Senthil, A.; Ravi, S.; Mitty, R.; Parasuraman, K.; et al. Recent development on carbon based heterostructures for their applications in energy and environment: A review. J. Industrial Eng. Chem. 2018, 64, 16-59.

73. Jamal, M.K.; Sami, A.A.; Rajivgandhi, G.; Chenthis, K.C.; Muthuchamy, M.; Naiyf, S.A.; Shine, K.; Reya, I.; Sevanan, M.; Wen-Jun, L. Laccase producing bacteria influenced the high decolorization of textile azo dyes with advanced study. Environ Res. 2021, 207, 112211. [CrossRef]

74. Alsaiari, N.S.; Abdelfattah, A.; Khadijah, M.K.; Alzahrani, F.M.; Harharah, H.N.; Rebah, F.B.; Tahoon, M.A. The biocatalytic degradation of organic dyes using laccase immobilized magnetic nanoparticles. Appl. Sci. 2021, 11, 8216. [CrossRef]

75. Sridharan, R.; Krishnaswamy, V.G.; Archana, K.M.; Rajagopal, R.; Thirumal, K.D.; George, C.; Doss, P. Integrated approach on azo dyes degradation using laccase enzyme and Cul nanoparticle. SN Appl. Sci. 2021, 370, 370. [CrossRef]

76. Routoula, E.; Siddharth, V.P. Degradation of Anthraquinone Dyes from Effluents: A Review Focusing on Enzymatic Dye Degradation with Industrial Potential. Environ. Sci. Technol. 2020, 54, 647-664. [CrossRef] [PubMed]

77. Qin, P.; Wu, Y.; Bilal, A.; Wang, J.; Gu, Y.; Yu, X.; Zhao, K.; Zhang, X.; Ma, M.; Chen, Q.; et al. Optimization of Laccase from Ganoderma lucidum Decolorizing Remazol Brilliant Blue R and Glac1 as Main Laccase-Contributing Gene. Molecules 2019, 24,3914 [CrossRef] [PubMed]

78. Mohanty, S.S.; Kumar, A. Enhanced degradation of anthraquinone dyes by microbial monoculture and developed consortium through the production of specific enzymes. Sci. Rep. 2021, 11, 7678. [CrossRef] [PubMed]

79. Sosa-Martíneza, J.D.; Balagurusamyb, N.; Montanez, J.; Peralta, R.A.; Moreira, R.F.P.M.; Bracht, A.; Peralta, R.M.; MoralesOyervides, L. Synthetic dyes biodegradation by fungal ligninolytic enzymes: Process optimization, metabolites evaluation and toxicity assessment. J. Hazard. Mater. 2020, 400, 123254. [CrossRef] [PubMed]

80. Ashutosh, Y.; Pooja, Y.; Anil, K.S.; Vyas, K.; Vijay, C.S.; Ram, N.B.; Abhay, R. Decolourisation of textile dye by laccase: Process evaluation and assessment of its degradation bioproducts. Bioresour. Technol. 2021, 340, 125591.

81. Kudanga, T.; Nyanhongo, G.S.; Guebitz, G.M.; Burton, S. Potential applications of laccase-mediated coupling and grafting reactions: A review. Enzyme Microb. Technol. 2011, 48, 195-208. [CrossRef]

82. Tauber, M.M.; Gubitz, G.M.; Rehorek, A. Degradation of azo dyes by oxidative processes-Laccase and ultrasound treatment. Bioresour. Technol. 2008, 99, 4213-4220. [CrossRef]

83. Campos, R.; Kandelbauer, A.; Robra, K.H.; CAvaco-Paulo, A.; Gubitz, G.M. Indigo degradation with purified laccases from Trametes hirsute and Sclerotium rolfsii. J. Biotechnol. 2001, 89, 131-139. [CrossRef]

84. Younes, S.B.; Sayadi, S. Detoxification of Indigo carmine using a combined treatment via a novel trimeric thermostable laccase and microbial consortium. J. Mol. Cat. B Enz. 2013, 87, 62-68. [CrossRef]

85. Abadulla, E.; Tzanov, T.; Costa, S.; Robra, K.H.; Cavaco-Paulo, A.; Gubitz, G.M. Decolorization and Detoxification of Textile Dyes with a Laccase from Trametes hirsuta. Appl. Environ. Microbiol. 2000, 66, 3357-3362. [CrossRef]

86. Rui, M.F.B.; Mafalda, R.A.; Pankaj, B.; Mara, G.F.; Ana, P.M. Improvements in the enzymatic degradation of textile dyes using ionic-liquid-based surfactants. Sep. Purif. Technol. 2020, 235, 116191.

87. Uygun, M.; Asunción-Nadal, V.; Evli, S.; Akta, D.; Jurado-Sánchez, B.; Escarpa, A. Dye removal by laccase-functionalized micromotors. Appl. Mater. Today 2021, 23, 101045. [CrossRef]

88. Khelifi, E.; Ayed, L.; Bouallagui, H.; Touhami, Y.; Hamdi, M. Effect of nitrogen and carbon sources on Indigo and Congo red decolourization by Aspergillus alliaceus strain 121C. J. Hazard Mater. 2009, 163, 1056-1062. [CrossRef] [PubMed]

89. Wang, H.; Zhang, W.; Zhao, J.; Xu, L.; Zhou, C.; Chang, L.; Wang, L. Rapid decolorization of phenolic azo dyes by immobilized laccase with $\mathrm{Fe}_{3} \mathrm{O}_{4} / \mathrm{SiO}_{2}$ nanoparticles as support. Ind. Eng. Chem. Res. 2013, 52, 4401-4407. [CrossRef]

90. Kunamneni, A.; Ghazi, I.; Camarero, S.; Ballesters, A.; Plou, F.J.; Alcalde, M. Decolorization of synthetic dyes by laccase immobilized on epoxy-activated carriers. Process Biochem. 2008, 43, 169-178. [CrossRef]

91. Qu, Y.; Shen, E.; Ma, Q.; Zhang, Z.; Liu, Z.; Shen, W.; Wang, J.; Li, D.; Li, H.; Zhou, J. Biodegradation of indole by a newly isolated Cupriavidus sp. SHE. J. Environ. Sci. 2015, 34, 126-132. [CrossRef]

92. Gu, C. Urbanization: Processes and driving forces. Sci. China Earth Sci. 2019, 62, 1351-1360. [CrossRef] 
93. Strobierski, T. Harvard Business School. Available online: https://online.hbs.edu/blog/post/globalization-effectsonenvironment (accessed on 15 November 2021).

94. Ebele, A.J.; Abou-Elwafa Abdallah, M.; Harrad, S. Pharmaceuticals and personal care products (PPCPs) in the freshwater aquatic environment. Emerg. Contam. 2017, 3, 1-16. [CrossRef]

95. Nikolaou, A.; Meric, S.; Fatta, D. Occurrence patterns of pharmaceuticals in water and wastewater environments. Anal. Bioanal. Chem. 2007, 387, 1225-1234. [CrossRef]

96. Singh, R. Biodegradation of xenobiotics-A way for environmental detoxification. Int. J. Dev. Res. 2017, 7, 14082-14087.

97. Štefanac, T.; Grgas, D.; Landeka Dragičević, T. Xenobiotics—Division and Methods of Detection: A Review. J. Xenobiot. 2021, 11, 9. [CrossRef] [PubMed]

98. de Oliveira, M.; Frihling, B.E.F.; Velasques, J.; Filho, F.J.C.M.; Cavalheri, P.S.; Migliolo, L. Pharmaceuticals residues and xenobiotics contaminants: Occurrence, analytical techniques and sustainable alternatives for wastewater treatment. Sci. Total Environ. 2020, 705, 135568. [CrossRef]

99. Kumar, D.; Chopra, S. Xenobiotic Compounds in the Environment: Their Fate, Transport and Removal. In Proceedings of the 3rd National Conference on Medical Instrumentation, Biomaterials and Signal Processing (NCMBS-20), Sonepat, India, 26-27 February 2020; pp. 96-102.

100. Mishra, S.; Lin, Z.; Pang, S.; Zhang, W.; Bhatt, P.; Chen, S. Recent Advanced Technologies for the Characterization of XenobioticDegrading Microorganisms and Microbial Communities. Front. Bioeng. Biotechnol. 2021, 9, 632059. [CrossRef] [PubMed]

101. Paul, D.; Pandey, G.; Pandey, J.; Jain, R.K. Accessing microbial diversity for bioremediation and environmental pollutant restoration. Trends Biotechnol. 2005, 23, 135-142. [CrossRef] [PubMed]

102. Perelo, L.W. In situ and bioremediation of organic pollutants in aquatic sediments. J. Hazard. Mater. 2010, 177, 81-89. [CrossRef] [PubMed]

103. Ortiz, H.M.L.; Salinas, E.S.; Gonzalez, E.D.; Godnez, M.L.C. Pesticide biodegradation: Mechanisms, genetics and strategies to enhance the process. In Biodegradation—Life of Science; Chamy, R., Rosenkranz, F., Eds.; InTech Open: Rijeka, Croatia, 2013; pp. 251-287.

104. Singh, A.; Chaudhary, S.; Dubey, B.; Prasad, V. Microbial-mediated management of organic xenobiotic pollutants in agricultural lands. In Plant Response to Xenobiotics; Singh, A., Prasad, S.M., Singh, R.P., Eds.; Springer: Singapore, 2016; pp. 211-230. [CrossRef]

105. Sathishkumar, M.; Binupriya, A.R.; Balk, S.; Yun, S. Biodegradation of crude oil by individual bacterial strains and mixed bacterial consortium isolated from hydrocarbon contaminated areas. Clean 2008, 36, 92-96. [CrossRef]

106. Nzila, A. Update on the catabolism of organic pollutant by bacteria. Environ. Pollut. 2013, 178, 474-482. [CrossRef]

107. Sunita, V.J.; Dolly, P.R.; Bateja, S.; Vivek, U.N. Isolation and screening for hydrocarbon utilizing bacteria (HUB) from petroleum samples. Int. J. Curr. Appl. Sci. 2013, 2, 48-60.

108. Zhao, Q.; Yue, S.; Bilal, M.; Hu, H.; Wang, W.; Zhang, X. Comparative genomic analysis of 26 Sphingomonas and Sphingobium strains: Dissemination of bioremediation capabilities, biodegradation potential and horizontal gene transfer. Sci. Total Environ. 2017, 609, 1238-1247. [CrossRef]

109. Bharadwaj, A. Bioremediation of xenobiotics: An eco-friendly cleanup approach. In Green Chemistry in Environmental Sustainability and Chemical Education; Parmar, V.S., Malhotra, P., Mathur, D., Eds.; Springer: Singapore, 2018; pp. 1-13. [CrossRef]

110. Yang, T.; Ren, L.; Jia, Y.; Fan, S.; Wang, J.; Nahurira, R. Biodegradation of di-(2-ethylhexyl) phthalate by Rhodococcus ruber YC-YT1 in contaminated water and soil. Int. J. Environ. Res. Public Health 2018, 15, 964. [CrossRef]

111. Yu, Y.; Yin, H.; Peng, H.; Lu, G.; Dang, Z. Proteomic mechanism of decabromodiphenyl ether (BDE-209) biodegradation by Microbacterium Y2 and its potential in remediation of BDE-209 contaminated water-sediment system. J. Hazard. Mater. 2019, 387, 121708. [CrossRef] [PubMed]

112. Bhatt, P.; Rene, E.R.; Kumar, A.J.; Zhang, W.; Chen, S. Binding interaction of allethrin with esterase: Bioremediation potential and mechanism. Bioresour. Technol. 2020, 315, 123845. [CrossRef] [PubMed]

113. Zhu, F.; Doyle, E.; Zhu, C.; Zhou, D.; Gu, C.; Gao, J. Metagenomic analysis exploring microbial assemblages and functional genes potentially involved in di (2-ethylhexyl) phthalate degradation in soil. Sci. Total Environ. 2020, 715, 137037. [CrossRef] [PubMed]

114. Jaiswal, S.; Singh, D.K.; Shukla, P. Gene editing and systems biology tools for pesticide bioremediation: A review. Front. Microiol. 2019, 10, 87. [CrossRef]

115. Phale, P.S.; Sharma, A.; Gautam, K. Microbial degradation of xenobiotics like aromatic pollutants from the terrestrial environments. In Pharmaceutical and Personal Care Products: Waste Management and Treatment Technology Emerging Contaminants and Micro Pollutants; Prasad, M.N.V., Vithanage, M., Kapley, A., Eds.; Elsevier: Amsterdam, The Netherlands, 2019; pp. 259-278. [CrossRef]

116. French, K.E.; Zhou, Z.; Terry, N. Horizontal 'gene drives' harness indigenous bacteria for bioremediation. Sci. Rep. 2020, 10, 15091. [CrossRef]

117. Kaur, H.; Kaur, G. Application of ligninolytic potentials of a white-rot fungus Ganoderma lucidum for degradation of lindane. Environ. Monit. Assess. 2016, 188, 588. [CrossRef]

118. Zhang, W.; Pang, S.; Lin, Z.; Mishra, S.; Bhatt, P.; Chen, S. Biotransformation of perfluoroalkyl acid precursors from various environmental systems: Advances and perspectives. Environ. Pollut. 2021, 268, 115908. [CrossRef]

119. Awasthi, K.R.; Awasthi, M.S. Health and environmental effects of organochlorine pesticides in developing countries. Open Access J. Environ. Soil Sci. 2019, 2, 206-208. [CrossRef] 
120. Cuozzo, S.A.; Sineli, P.E.; Davila Costa, J.; Tortella, G. Streptomyces sp. is a powerful biotechnological tool for the biodegradation of HCH isomers: Biochemical and molecular basis. Crit. Rev. Biotechnol. 2017, 38, 719-728. [CrossRef]

121. Zhang, W.; Lin, Z.; Pang, S.; Bhatt, P.; Chen, S. Insights into the biodegradation of lindane ( $\gamma$-hexacholocyclohexane) using a microbial system. Front. Microbiol. 2020, 11, 522. [CrossRef]

122. Ademakinwa, A.N. A heat-resistant intracellular laccase immobilized via cross-linked enzyme aggregate preparation: Characterization, application in bisphenol a removal and phytotoxicity evaluation. J. Hazard. Mat. 2021, 419, 126480. [CrossRef] [PubMed]

123. Giardina, P.; Faraco, V.; Pezzella, C.; Piscitelli, A.; Vanhulle, S.; Sannia, G. Laccases: A never-ending story. Cell. Mol. Life Sci. 2009, 67, 369-385. [CrossRef] [PubMed]

124. Bilal, M.; Iqbal, H.M.N.; Barcel'o, D. Mitigation of bisphenol A using an array of laccase-based robust bio-catalytic cues-a review. Sci. Total Environ. 2019, 689, 160-177. [CrossRef] [PubMed]

125. Sridharan, R.; Krishnaswamy, V.; Kumar, P.S.; Vidhya, T.A.; Sivamurugan, V.; Kumar, D.T.; Doss, C.G.P.; Vo, D.V.N. Analysis and effective separation of toxic pollutants from water resources using MBBR: Pathway prediction using alkaliphilic P. mendocina. Sci. Total Environ. 2021, 797, 149135. [CrossRef] [PubMed]

126. Malik, E.M.; Müller, C.E. Anthraquinones as pharmacological tools and drugs. Med. Res. Rev. 2016, 36, 705-748. [CrossRef]

127. Soares, G.M.B.; Costa-Ferreira, M.; Pessoa de Amorim, M.T. Decolorization of an anthraquinone-type dye using a laccase formulation. Bioresour. Technol. 2001, 79, 171-177. [CrossRef]

128. Peng, J.; Wu, E.; Lou, X.; Deng, Q.; Hou, X.; Lv, C.; Hu, Q. Anthraquinone removal by a metal-organic framework/polyvinyl alcohol cryogel-immobilized laccase: Effect and mechanism exploration. Chem. Eng. J. 2021, 418, 129473. [CrossRef]

129. Imam, A.; Suman, S.K.; Singh, R.; Vempatapu, B.P.; Ray, A.; Kanaujia, P.K. Application of laccase immobilized rice straw biochar for anthracene degradation. Environ. Pollut. 2021, 268, 115827. [CrossRef]

130. Wen, X.; Du, C.; Wan, J.; Zeng, G.; Huang, D.; Yin, L.; Deng, R.; Tan, S.; Zhang, J. Immobilizing laccase on kaolinite and its application in treatment of malachite green effluent with the coexistence of Cd (П). Chemosphere 2019, 217, 843-850. [CrossRef]

131. Al Farraj, D.A.; Elshikh, M.S.; Al Khulaifi, M.M.; Hadibarata, T.; Yuniarto, A.; Syafiuddin, A. Biotransformation and detoxification of antraquione dye green 3 using Halophilic hortaea sp. Int. Biodeterior. Biodegrad. 2019, 140, 72-77. [CrossRef]

132. Dao, A.T.N.; Vonck, J.; Janssens, T.K.S.; Dang, H.T.C.; Brouwer, A.; de Boer, T.E. Screening white-rot fungi for bioremediation potential of 2,3,7,8-tetrachlorodibenzo-p-dioxin. Ind. Crop. Prod. 2019, 128, 153-161. [CrossRef]

133. Hadibarata, T.; Yuniarto, A. Biodegradation of polycyclic aromatic hydrocarbons by high-laccase basidiomycetes fungi isolated from tropical forest of Borneo. Biocatal. Agric. Biotechnol. 2020, 28, 101717. [CrossRef]

134. Rajput, M.S.; Dwivedi, V.; Awasthi, S.K. Biodegradation of pyridine raffinate by microbial laccase isolated from Pseudomonas monteilii \& Gamma proteobacterium present in woody soil. Biocatal. Agric. Biotechnol. 2020, 26, 101650. [CrossRef]

135. Dao, A.T.N.; Loenen, S.J.; Swart, K.; Dang, H.T.C.; Brouwer, A.; de Boer, T.E. Characterization of 2,3,7,8-tetrachlorodibenzop-dioxin biodegradation by extracellular lignin-modifying enzymes from ligninolytic fungus. Chemosphere 2021, 263, 28280. [CrossRef] [PubMed]

136. Enayatizamir, N.; Jing, L.; Li, W.; Lin, X.; Fu, P. Coupling Laccase production from Trametes pubescence with heavy metal removal for Economic Waste Water Treatment. J. Water Process Eng. 2020, 37, 101357. [CrossRef]

137. Vipotnik, Z.; Michelin, M.; Tavares, T. Development of a packed bed reactor for the removal of aromatic hydrocarbons from soil using laccase/mediator feeding system. Microbiol. Res. 2021, 245, 126687. [CrossRef]

138. Rahmani, H.; Lakzian, A.; Karimi, A.; Halajnia, A. Efficient removal of 2,4-dinitrophenol from synthetic wastewater and contaminated soil samples using free and immobilized laccases. J. Environ. Manag. 2020, 256, 109740. [CrossRef]

139. Rudakiya, D.M.; Patel, D.H.; Gupte, A. Exploiting the potential of metal and solvent tolerant laccase from Tricholoma giganteum AGDR1 for the removal of pesticides. Int. J. Biol. Macromol. 2020, 144, 586-595. [CrossRef]

140. Mir-Tutusaus, J.A.; Masís-Mora, M.; Corcellas, C.; Eljarrat, E.; Barceló, D.; Sarrà, M.; Caminal, G.; Vicent, T.; Rodríguez-Rodríguez, C.E. Degradation of selected agrochemicals by the white rot-fungus Trametes versicolor. Sci. Total Environ. 2014, 500, 235-242. [CrossRef]

141. Chen, X.; Zhou, Q.; Liu, F.; Peng, Q.; Bian, Y. Performance and kinetic of pesticide residues removal by microporous starch immobilized laccase in a combined adsorption and biotransformation process. Environ. Technol. Innov. 2021, 21, 101235. [CrossRef]

142. UNEP. Stockholm Convention on Persistent Organic Pollutions (POPs). 2017. Available online: https://wedocs.unep.org/ bitstream/handle/20.500.11822/31829/RUEPIRDA.pdf?sequence=1\&isAllowed=y (accessed on 15 December 2021).

143. Germain, J.; Raveton, M.; Binet, M.N.; Mouhamadou, B. Screening and metabolic potential of fungal strains isolated from contaminated soil and sediment in the polychlorinated biphenyl degradation. Ecotoxicol. Environ. Saf. 2021, $208,111703$. [CrossRef] [PubMed]

144. Bhalla, R.; Tehrani, R.; Van Aken, B. Toxicity of hydroxylated polychlorinated biphenyls (HO-PCBs) using the bioluminescent assay Microtox®. Ecotoxicology 2016, 25, 1438-1444. [CrossRef] [PubMed]

145. Corrales, J.; Kristofco, L.A.; Baylor Steele, W.; Yates, B.S.; Breed, C.S.; Williams, E.S.; Brooks, B.W. Global assessment of bisphenol A in the environment: Review and analysis of its occurrence and bioaccumulation. Dose-Response 2015, 13, 1559325815598308. [CrossRef] [PubMed]

146. Onaizi, S.A.; Alshabib, M. The degradation of bisphenol A by laccase: Effect of biosurfactant addition on the reaction kinetics under various conditions. Sep. Purif. Technol. 2021, 257, 117785. [CrossRef] 
147. Guardado, A.L.P. Enzymatic Degradation of Recalcitrant Pharmaceutical Micropollutants. Ph.D. Thesis, Université Montpellier, Montpellier, France, 10 May 2019.

148. Gholami, P.; Khataee, A.; Soltani, R.D.C.; Dinpazhoh, L.; Bhatnagar, A. Photocatalytic degradation of gemifloxacin antibiotic using Zn-Co-LDH@ biochar nanocomposite. J. Hazard. Mater. 2020, 382, 121070. [CrossRef]

149. Wang, S.; Ma, X.; Liu, Y.; Yi, X.; Du, G.; Li, J. Fate of antibiotics, antibiotic-resistant bacteria, and cell-free antibiotic-resistant genes in full-scale membrane bioreactor wastewater treatment plants. Bioresour. Technol. 2020, 302, 122825. [CrossRef] [PubMed]

150. Guardado, A.L.P.; Belleville, M.-P.; Alanis, M.J.R.; Saldivar, R.P.; Sanchez-Marcano, J. Effect of redox mediators in pharmaceuticals degradation by laccase: A comparative study. Process Biochem. 2019, 78, 123-131. [CrossRef]

151. Cruz-Morató, C.; Ferrando-Climent, L.; Rodriguez-Mozaz, S.; Barceló, D.; Marco-Urrea, E.; Vicent, T.; Sarrà, M. Degradation of pharmaceuticals in non-sterile urban wastewater by Trametes versicolor in a fluidized bed bioreactor. Water Res. 2013, 47, 5200-5210. [CrossRef]

152. Cruz-Morató, C.; Lucas, D.; Llorca, M.; Rodriguez-Mozaz, S.; Gorga, M.; Petrovic, M.; Barceló, D.; Vicent, T.; Sarrà, M.; MarcoUrrea, E. Hospital wastewater treatment by fungal bioreactor: Removal efficiency for pharmaceuticals and endocrine disruptor compounds. Sci. Total Environ. 2014, 493, 365-376. [CrossRef]

153. Castellet-Rovira, F.; Lucas, D.; Villagrasa, M.; Rodríguez-Mozaz, S.; Barceló, D.; Sarrà, M. Stropharia rugosoannulata and Gymnopilus luteofolius: Promising fungal species for pharmaceutical biodegradation in contaminated water. J. Environ. Manag. 2018, 207, 396-404. [CrossRef]

154. Gao, P.; Ding, Y.; Li, H.; Xagoraraki, I. Occurrence of pharmaceuticals in a municipal wastewater treatment plant: Mass balance and removal processes. Chemosphere 2012, 88, 17-24. [CrossRef] [PubMed]

155. Ratola, N.; Cincinelli, A.; Alves, A.; Katsoyiannis, A. Occurrence of organic microcontaminants in the wastewater treatment process. A mini review. J. Hazard. Mater. 2012, 239-240, 1-18. [CrossRef] [PubMed]

156. Verlicchi, P.; Al Aukidy, M.; Zambello, E. Occurrence of pharmaceutical compounds in urban wastewater; Removal, mass load and environmental risk after a secondary treatment-A review. Sci. Total Environ. 2012, 429, 123-155. [CrossRef]

157. Gasser, C.A.; Ammann, E.M.; Shahgaldian, P.; Corvini, P.F.X. Laccases to take on the challenge of emerging organic contaminants in wastewater. Appl. Microbiol. Biotechnol. 2014, 98, 9931-9952. [CrossRef] [PubMed]

158. Rodríguez-Delgado, M.; Orona-Navar, C.; García-Morales, R.; Hernandez-Luna, C.; Parra, R.; Mahlknecht, J.; Ornelas-Soto, N. Biotransformation kinetics of pharmaceutical and industrial micropollutants in groundwaters by a laccase cocktail from Pycnoporus sanguineus CS43 fungi. Int. Biodeterior. Biodegrad. 2016, 108, 34-41. [CrossRef]

159. Jolivalt, C.; Brenon, S.; Caminade, E.; Mougin, C.; Pontié, M. Immobilization of laccase from Trametes versicolor on a modified PVDF microfiltration membrane: Characterization of the grafted support and application in removing a phenylurea pesticide in wastewater. J. Membr. Sci. 2000, 180, 103-113. [CrossRef]

160. Ferrando-Climent, L.; Cruz-Morat'o, C.; Marco-Urrea, E.; Vicent, T.; Sarrà, M.; Rodriguez-Mozaz, S.; Barcel 'o, D. Nonconventional biological treatment based on Trametes versicolor for the elimination of recalcitrant anticancer drugs in hospital wastewater. Chemosphere 2015, 136, 9-19. [CrossRef]

161. Haroune, L.; Saibi, S.; Bellenger, J.P.; Cabana, H. Evaluation of the efficiency of Trametes hirsuta for the removal of multiple pharmaceutical compounds under low concentrations relevant to the environment. Bioresour. Technol. 2014, 171, 199-202. [CrossRef]

162. Mir-Tutusaus, J.A.; Parladé, E.; Llorca, M.; Villagrasa, M.; Barceló, D.; Rodriguez-Mozaz, S.; Martinez-Alonso, M.; Gaju, N.; Caminal, G.; Sarrà, M. Pharmaceuticals removal and microbial community assessment in a continuous fungal treatment of non-sterile real hospital wastewater after a coagulation-flocculation pretreatment. Water Res. 2017, 116, 65-75. [CrossRef]

163. Pereira, C.S.; Kelbert, M.; Daronch, N.A.; Michels, C.; de Oliveira, D.; Soares, H.M. Potential of enzymatic process as an innovative technology to remove anticancer drugs in wastewater. Appl. Microbiol Biotechnol. 2020, 104, 23-31. [CrossRef]

164. Suda, T.; Hata, T.; Kawai, S.; Okamura, H.; Nishida, T. Treatment of tetracycline antibiotics by laccase in the presence of 1-hydroxybenzotriazole. Bioresour. Technol. 2012, 103, 498-501. [CrossRef] [PubMed]

165. Yang, J.; Lin, Y.; Yang, X.; Ng, T.B.; Ye, X.; Lin, J. Degradation of tetracycline by immobilized laccase and the proposed transformation pathway. J. Hazard. Mater. 2017, 322, 525-531. [CrossRef]

166. Shao, B.; Liu, Z.; Zeng, G.; Liu, Y.; Yang, X.; Zhou, C.; Chen, M.; Liu, Y.; Jiang, Y.; Yan, M. Immobilization of laccase on hollow mesoporous carbon nanospheres: Noteworthy immobilization, excellent stability and efficacious for antibiotic contaminants removal. J. Hazard. Mater. 2019, 362, 318-326. [CrossRef] [PubMed]

167. Schwarz, J.; Aust, M.-O.; Thiele-Bruhn, S. Metabolites from fungal laccase-catalysed transformation of sulfonamides. Chemosphere 2010, 81, 1469-1476. [CrossRef] [PubMed]

168. Navada, K.K.; Kulal, A. Enzymatic degradation of chloramphenicol by laccase from Trametes hirsuta and comparison among mediators. Int. Biodeterior. Biodegrad. 2019, 138, 63-69. [CrossRef]

169. Jureczko, M.; Przystas, W.; Krawczyk, T.; Gonciarz, W.; Rudnicka, K. White-rot fungi-mediated biodegradation of cytostatic drugs-bleomycin and vincristine. J. Hazard. Mater. 2021, 407, 124632. [CrossRef]

170. Kelbert, M.; Pereira, C.S.; Daronch, N.A.; Cesca, K.; Michels, C.; de Oliveira, D.; Soares, H.M. Laccase as an efficacious approach to remove anticancer drugs: A study of doxorubicin degradation, kinetic parameters, and toxicity assessment. J. Hazard. Mater. 2021, 409, 124520. [CrossRef] 
171. Aracagök, Y.D.; Göker, H.; Cihangir, N. Biodegradation of diclofenac with fungal strains. Arch. Environ. Prot. 2018, 44, 55-62. [CrossRef]

172. Yusnidar, Y. The Utilization of Laccase-Functionalized Graphene Oxide as an Effective Biodegradation of Pharmaceutical Industry Waste: Diclofenac and Ibuprofen. Sys. Rev. Pharm. 2020, 11, 536-544. [CrossRef]

173. Zdarta, J.; Jankowska, K.; Wyszowska, M.; Kijeńska-Gawrońska, E.; Zgoła-Grześkowiak, A.; Pinelo, M.; Meyer, A.S.; Moszyński, D.; Jesionowski, T. Robust biodegradation of naproxen and diclofenac by laccase immobilized using electrospun nanofibers with enhanced stability and reusability. Mater. Sci. Eng. C 2019, 103, 109789. [CrossRef]

174. Masjoudi, M.; Golgoli, M.; Nejad, Z.G.; Sadeghzadeh, S.; Borghei, S.M. Pharmaceuticals removal by immobilized laccase on polyvinylidene fluoride nanocomposite with multi-walled carbon nanotubes. Chemosphere 2021, 263, 128043. [CrossRef] [PubMed]

175. Hachi, M.; Chergui, A.; Yeddou, A.R.; Selatnia, A.; Cabana, H. Removal of acetaminophen and carbamazepine in single and binary systems with immobilized laccase from Trametes hirsuta. J. Biocatal. Biotransform. 2017, 35, 51-62. [CrossRef]

176. Primožič, M.; Kravanja, G.; Knez, Ž.; Crnjac, A.; Leitgeb, M. Immobilized laccase in the form of (magnetic) cross-linked enzyme aggregates for sustainable diclofenac (bio)degradation. J. Clean. Prod. 2020, 275, 124121. [CrossRef]

177. Lloret, L.; Eibes, G.; Lú-Chau, T.A.; Moreira, M.T.; Feijoo, G.; Lema, J.M. Laccase-catalyzed degradation of anti-inflammatories and estrogens. Biochem. Eng. J. 2010, 51, 124-131. [CrossRef]

178. Tran, N.H.; Urase, T.; Kusakabe, O. Biodegradation characteristics of pharmaceutical substances by whole fungal culture Trametes versicolor and its laccase. J. Water Environ. Technol. 2010, 8, 125-140. [CrossRef]

179. Jahangiri, E.; Thomas, I.; Schulze, A.; Seiwert, B.; Cabana, H.; Schlosser, D. Characterisation of electron beam irradiationimmobilised laccase for application in wastewater treatment. Sci Total Environ. 2018, 624, 309-322. [CrossRef]

180. Kang, B.R.; Kim, S.Y.; Kang, M.; Lee, T.K. Removal of pharmaceuticals and personal care products using native fungal enzymes extracted during the ligninolytic process. Environ. Res. 2021, 195, 110878. [CrossRef]

181. Alharbi, S.K.; Nghiem, L.D.; van de Merwe, J.P.; Leusch, F.D.L.; Asif, M.B.; Hai, F.I.; Price, W.E. Degradation of diclofenac, trimethoprim, carbamazepine, and sulfamethoxazole by laccase from Trametes versicolor: Transformation products and toxicity of treated effluent. Biocatal. Biotransform. 2019, 37, 399-408. [CrossRef]

182. Taheran, M.; Naghdi, M.; Brar, S.K.; Knystautas, E.J.; Verma, M.; Surampalli, R.Y. Covalent Immobilization of Laccase onto Nanofibrous Membrane for Degradation of Pharmaceutical Residues in Water. ACS Sustain. Chem. Eng. 2017, 5, 10430-10438. [CrossRef]

183. Naghdi, M.; Taheran, M.; Brar, S.K.; Kermanshahi-pour, A.; Verma, M.; Surampalli, R.Y. Biotransformation of carbamazepine by laccase-mediator system: Kinetics, by-products and toxicity assessment. Process Biochem. 2018, 67, 147-154. [CrossRef]

184. Inoue, Y.; Hata, T.; Kawai, S.; Okamura, H.; Nishida, T. Elimination and detoxification of triclosan by manganese peroxidase from white rot fungus. J. Hazard. Mater. 2010, 180, 764-767. [CrossRef] [PubMed]

185. Kim, Y.-J.; Nicell, J.A. Laccase-catalysed oxidation of aqueous triclosan. J. Chem. Technol. Biotechnol. 2006, 81, 1344-1352. [CrossRef]

186. Nguyen, L.N.; Hai, F.I.; Price, W.E.; Leusch, F.D.L.; Roddick, F.; Ngo, H.H.; Guo, W.; Magram, S.F.; Nghiem, L.D. The effects of mediator and granular activated carbon addition on degradation of trace organic contaminants by an enzymatic membrane reactor. Bioresour. Technol. 2014, 167, 169-177. [CrossRef] [PubMed] 